San Jose State University

SJSU ScholarWorks

Faculty Publications, Meteorology and Climate

Science

Meteorology and Climate Science

December 2014

\title{
Optimal Ranking Regime Analysis of Intra- to Multidecadal U.S. Climate Variability. Part II: Precipitation and Streamflow
}

Steven A. Mauget

U.S. Department of Agriculture, Lubbock, Texas

Eugene C. Cordero

San Jose State University, eugene.cordero@sjsu.edu

Follow this and additional works at: https://scholarworks.sjsu.edu/meteorology_pub

Part of the Atmospheric Sciences Commons, Climate Commons, and the Meteorology Commons

\section{Recommended Citation}

Steven A. Mauget and Eugene C. Cordero. "Optimal Ranking Regime Analysis of Intra- to Multidecadal U.S. Climate Variability. Part II: Precipitation and Streamflow" Journal of Climate (2014): 9027-9049.

https://doi.org/10.1175/JCLI-D-14-00041.1

This Article is brought to you for free and open access by the Meteorology and Climate Science at SJSU ScholarWorks. It has been accepted for inclusion in Faculty Publications, Meteorology and Climate Science by an authorized administrator of SJSU ScholarWorks. For more information, please contact scholarworks@sjsu.edu. 


\title{
Optimal Ranking Regime Analysis of Intra- to Multidecadal U.S. Climate Variability. Part II: Precipitation and Streamflow*
}

\author{
Steven A. Mauget \\ Plant Stress and Water Conservation Laboratory, Agricultural Research Service, U.S. Department of \\ Agriculture, Lubbock, Texas \\ EUGENE C. CORDERO \\ Department of Meteorology and Climate Science, San José State University, San Jose, California
}

(Manuscript received 9 January 2014, in final form 11 September 2014)

\begin{abstract}
In Part I of this paper, the optimal ranking regime (ORR) method was used to identify intradecadal to multidecadal (IMD) regimes in U.S. climate division temperature data during 1896-2012. Here, the method is used to test for annual and seasonal precipitation regimes during that same period. Water-year mean streamflow rankings at 125 U.S. Hydro-Climatic Data Network gauge stations are also evaluated during 19392011. The precipitation and streamflow regimes identified are compared with ORR-derived regimes in the Pacific decadal oscillation (PDO), the Atlantic multidecadal oscillation (AMO), and indices derived from gridded SST anomaly (SSTA) analysis data. Using a graphic display approach that allows for the comparison of IMD climate regimes in multiple time series, an interdecadal cycle in western precipitation is apparent after 1980, as is a similar cycle in northwestern streamflow. Before 1980, IMD regimes in northwestern streamflow and annual precipitation are in approximate antiphase with the PDO. One of the clearest IMD climate signals found in this analysis are post-1970 wet regimes in eastern U.S streamflow and annual precipitation, as well as in fall [September-November (SON)] precipitation. Pearson correlations between time series of annual and seasonal precipitation averaged over the eastern United States and SSTA analysis data show relatively extensive positive correlations between warming tropical SSTA and increasing fall precipitation. The possible Pacific and northern Atlantic roots of the recent eastern U.S. wet regime, as well as the general characteristics of U.S. climate variability in recent decades that emerge from this analysis and that of Part I, are discussed.
\end{abstract}

\section{Introduction}

The analysis of climate variability has traditionally relied on trend analysis (e.g., Roden 1962; Spar and Ronberg 1968; Reiter and Westhoff 1982; Lettenmaier et al. 1994; Karl et al. 1996; Groisman and Easterling 1994; Groisman et al. 2001; Trenberth et al. 2007), and this reliance has continued in more recent work (Wang et al. 2009; Hoerling et al. 2010; Mass et al. 2011; Kochendorfer and

\footnotetext{
* Supplemental information related to this paper is available at the Journals Online website: http://dx.doi.org/10.1175/JCLI-D-1400041.s1.

Corresponding author address: Steven A. Mauget, USDA Plant Stress and Water Conservation Laboratory, 3810 4th Street, Lubbock, TX 79415 .

E-mail: steven.mauget@ars.usda.gov
}

Hubbart 2010; Hodgkins and Dudley 2011; Hartmann et al. 2014). However, there is also growing recognition that describing climate in terms of how it projects on linear trends can be misleading or unrepresentative. Barbosa (2011) demonstrated that linear trends are inadequate for describing long-term global sea surface temperature variability. When applied to climate records that are essentially cyclic or have abrupt regime transitions, the magnitude, significance, and signs of trends can be sensitive to the choice of start and end years defining the trend-fitting period (Hartmann and Wendler 2005; Chapman and Walsh 2007; Lins and Cohn 2011; Kumar et al. 2013; Hartmann et al. 2014). One remedy for this problem is to calculate trend values over a prescribed range of possible start and end years and then graph the variation in increasing and decreasing trends (McCabe and Wolock 2002; Liebmann et al. 2010; Peterson et al. 2013). Other options include 
calculating trends over moving time windows of fixed duration (Kumar et al. 2013; Sheffield et al. 2013), using wavelet analysis to identify optimal trend-fitting periods (Karl et al. 2000), and solving for optimal continuous piecewise trend-fitting periods subject to simultaneous constraints (Miranda and Tomé 2009). Similar approaches are likely necessary in describing North American climate over multidecadal time scales, where the Pacific decadal oscillation (PDO; Mantua et al. 1997; Gershunov and Barnett 1998; Barlow et al. 2001; Hartmann and Wendler 2005; Wang et al. 2009; Dai 2013) and the Atlantic multidecadal oscillation (AMO; Enfield et al. 2001; McCabe et al. 2004, 2008; Sutton and Hodson 2005, 2007; Kumar et al. 2013) have been shown to influence climate. However, trend fitting may not be the best choice as the basis for schemes to detect similarly cyclic features in U.S. climate. In trying to identify nonlinear variability using a linear test these exhaustive or optimized trend-fitting methods may be, in effect, trying to force linear "pegs" into nonlinear "holes."

In a series of papers (Mauget 2003a,b, 2004, 2006; Cordero et al. 2011), intradecadal to multidecadal (IMD) variability in temperature, precipitation, and streamflow has been identified via a method that calculates MannWhitney $Z$ statistics over moving time windows of varying durations. In Mauget and Cordero (2014, hereafter Part I), this approach-referred to here as the optimal ranking regime (ORR) method-was used to detect IMD variation in U.S. climate division temperature series during 1896-2012. Here, ORR analysis is applied to annual and seasonal climate division precipitation series during that same period. This method is also used to detect IMD regimes in water-year average streamflow during 1939-2011 derived from the most recent data available from the U.S. Hydro-Climatic Data Network (HCDN). As in Part I, the most significant ranking regimes identified in U.S. precipitation and streamflow will be compared with regimes found in the ORR analysis of annual AMO and PDO time series. Given the wet conditions found here over the eastern United States after 1970, the seasonality and roots of that wet regime are also explored via Pearson correlations with gridded SST anomaly (SSTA) analyses during 1896-2012.

Section 2 will describe the climate division precipitation, HCDN streamflow, PDO, AMO, and SSTA analysis data. Section 3 will describe the ORR method and demonstrate it on a time series of annual precipitation averaged over the continental United States. Section 4 will present the results of the ORR analyses of annual, winter, spring, summer, and fall precipitation data at the climate division level and the correlations of eastern U.S. precipitation time series with the SSTA analyses. Section 5 will present the ORR analysis of the
HCDN streamflow rankings. Section 6 will summarize the results of sections 4 and 5, discuss the seasonality of the recent eastern U.S. wet period and its possible $\mathrm{Pa}$ cific and Atlantic roots, and summarize the general features of U.S climate variation in recent decades that are evident from this analysis and Part I.

\section{Data}

\section{a. U.S. climate division data}

Monthly climate division precipitation data (Guttman and Quayle 1996) are derived from regional averages of rainfall equivalent monthly station precipitation data. Although the data reported by the National Climate Data Center (NCDC) are averaged over 344 climate divisions, the data used here were aggregated from the NCDC data into 102 divisions (Fig. 1a) by the National Oceanic and Atmospheric Administration (NOAA) Climate Prediction Center (CPC).

Climate division data are well suited for detecting IMD variability in U.S. climate, as their primary purpose is to assess long-period or century-scale climate features (Guttman and Quayle 1996). The main feature that allows the data to accomplish this is their duration and continuity in time. The CPC data used here extend continuously from January 1895 to December 2012. As in Part I, monthly CPC divisional precipitation (DPCP) values were accumulated over annual (January-December), winter [December-February (DJF)], spring [MarchMay (MAM)], summer [June-August (JJA)], and fall [September-November (SON)] periods. Winter precipitation totals are associated with the year in which January and February occurs; thus, 117 annual and seasonal precipitation values for each CPC climate division are defined for the 1896-2012 calendar years. A second advantage is the data's spatial continuity over the continental United States, which, when combined with the graphic approach to displaying ranking regimes described in section 4, makes it useful for detecting the spatial extent of IMD climate effects.

Although divisional data are in some ways ideal for detecting IMD climate variation over the United States, there are potential problems in their use. Two problems, which are discussed in more detail in section 2a of Part I, can be traced to changes in how the data records are calculated and how station networks within divisions evolve over time. Climate division data were calculated from equal-weighted averages of station data after 1930 and were estimated via regression from statewide averages during 1895-1930. This resulted in a variance discontinuity where post-1930 data have increased variance relative to the earlier regression-derived values (Guttman and Quayle 1996). A second problem stems 
(a)

(b)
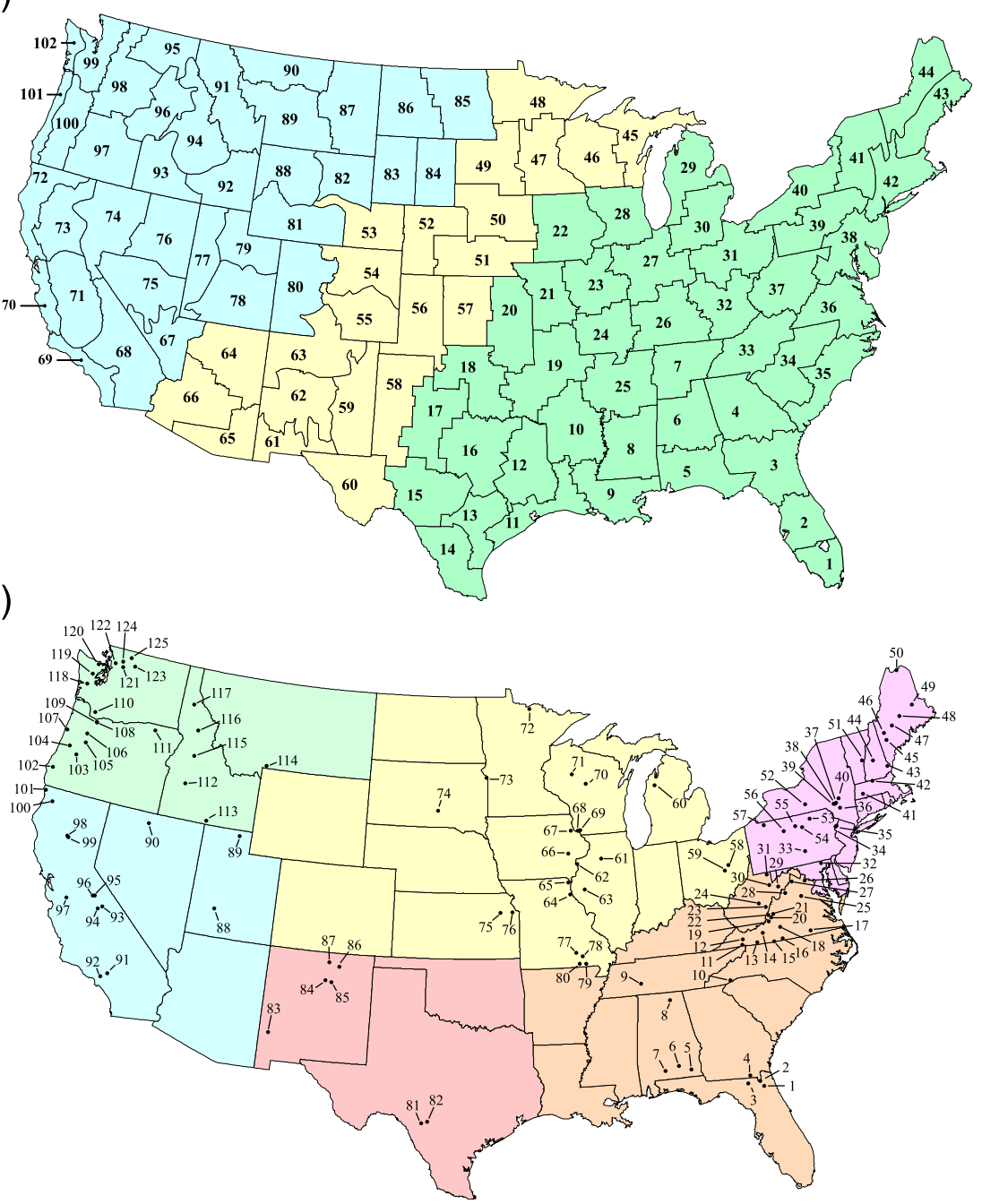

FIG. 1. (a) U.S. climate divisions as defined by the CPC. Green-, yellow-, and blue-shaded regions mark the EUS, CUS, and WUS regions used to locate a climate division's annual and seasonal precipitation regimes (in Figs. 4, 6, and 8-10). (b) Locations of the 125 HCDN-2009 streamflow gauge stations evaluated here during 1939-2011. The shaded areas show the southeastern (beige), northeastern (violet), midwestern (yellow), south-central (red), western (blue), and northwestern (green) U.S. regions used to locate the station's associated streamflow ranking regimes (in Fig. 11). Station names and watershed areas are listed in Table 1.

from the changing composition and density of station networks, particularly those with nonuniform and relatively sparse distributions in the west before 1931. Although the ranking-based ORR approach is insensitive to time-invariant data biases, it may be sensitive to biases that were gradually or abruptly introduced into the data during 1896-2012. Whether these two possible problems will influence the results found here will depend on their effect on the data's rank ordering. If data-related time-varying biases have influenced that ordering, the ORR-based graphic method used here may, in principle, be able to detect those effects. (For example, in Figs. 4-8 significant shifts in precipitation rankings might be evident in the data before and after 1930. On the other hand, identifying previously noted IMD variation before 1930 that is consistent over numerous climate divisions, particularly in the western United States, might indicate that these biases were not significant.)

\section{b. HCDN-2009 streamflow data}

By acting as a spatial integrator of precipitation, evapotranspiration, and soil moisture over a watershed's area, streamflow can serve as a continuous measure of 
TABLE 1. The $125 \mathrm{HCDN}-2009$ streamflow gauge stations and their associated watershed areas. Station locations are indicated by station number in Fig. 1 b.

\begin{tabular}{|c|c|c|c|c|c|}
\hline \multicolumn{3}{|c|}{ their associated watershed areas. Station locations are indicated by } & \\
\hline station numb & watersned areas. Station locations a & marcated by & \multirow{2}{*}{$\frac{\text { Station No. }}{35}$} & Station & \multirow{2}{*}{$\begin{array}{c}\begin{array}{l}\text { Watershed } \\
\text { area }\left(\mathrm{km}^{2}\right)\end{array} \\
167.7\end{array}$} \\
\hline Station No. & Station & $\begin{array}{l}\text { Watershed } \\
\text { area }\left(\mathrm{km}^{2}\right)\end{array}$ & & $\begin{array}{l}\text { Flat Brook near Flatbrookville, } \\
\text { NJ }\end{array}$ & \\
\hline 1 & $\begin{array}{l}\text { North Fork Black Creek near } \\
\text { Middleburg, FL }\end{array}$ & 451.1 & 36 & $\begin{array}{l}\text { Rondout Creek near Lowes } \\
\text { Corners, NY }\end{array}$ & 99.6 \\
\hline \multirow[t]{2}{*}{2} & St. Mary's River near & \multirow[t]{2}{*}{1748.4} & 37 & Mill Brook near Dunraven, NY & 64.5 \\
\hline & Macclenny, FL & & 38 & Tremper Kill near Andes, NY & 85.6 \\
\hline 3 & $\begin{array}{l}\text { Suwannee River at White } \\
\text { Springs, FL }\end{array}$ & 6136.3 & 39 & $\begin{array}{l}\text { East Branch Delaware River at } \\
\text { Margaretville, NY }\end{array}$ & 424.1 \\
\hline \multirow[t]{2}{*}{4} & \multirow{2}{*}{$\begin{array}{l}\text { Suwannee River at US } 441 \\
\text { at Fargo, GA }\end{array}$} & \multirow[t]{2}{*}{3322.2} & 40 & Schoharie Creek at Prattsville, NY & 612.5 \\
\hline & & & 41 & West Branch Westfield River at & 243.5 \\
\hline 5 & $\begin{array}{l}\text { Choctawhatchee River near } \\
\text { Newton, AL }\end{array}$ & 1781.6 & 42 & $\begin{array}{l}\text { Hunting, MA } \\
\text { Priest Brook near Winchendon, }\end{array}$ & 49.7 \\
\hline 6 & Conecuh River at Brantley, AL & 1292.8 & & MA & \\
\hline \multirow[t]{2}{*}{7} & Murder Creek near & \multirow[t]{2}{*}{445.7} & 43 & Oyster River near Durham, NH & 31.3 \\
\hline & Evergreen, AL & & 44 & Smith River near Bristol, NH & 222.5 \\
\hline 8 & $\begin{array}{l}\text { Paint Rock River near } \\
\text { Woodville, AL }\end{array}$ & 813.8 & 45 & $\begin{array}{l}\text { Little Androscoggin River near } \\
\text { South Paris, ME }\end{array}$ & 190.9 \\
\hline \multirow[t]{2}{*}{9} & Buffalo River near Flat & \multirow[t]{2}{*}{1163} & 46 & Swift River near Roxbury, ME & 250.6 \\
\hline & Woods, TN & & 47 & Carrabassett River near North & 909.1 \\
\hline \multirow[t]{2}{*}{10} & French Broad River at & \multirow[t]{2}{*}{178.7} & & Anson, ME & \\
\hline & Rosman, NC & & 48 & Piscataquis River near & 769 \\
\hline \multirow[t]{2}{*}{11} & South Fork Holston River & \multirow[t]{2}{*}{784.8} & & Dover-Foxcroft, ME & \\
\hline & near Damascus, VA & & 49 & Mattawamkeag River near & 3676.2 \\
\hline 12 & North Fork Holston River & 578.2 & & Mattawamkeag, ME & \\
\hline & near Saltville, VA & & 50 & Fish River near Fort Kent, ME & 2252.7 \\
\hline 13 & New River near Galax, VA & 2952.7 & 51 & White River at West Hartford, VT & 1790.2 \\
\hline 14 & Little River at Graysontown, VA & 794.6 & 52 & Cayuga Inlet near Ithaca, NY & 91.9 \\
\hline 15 & $\begin{array}{l}\text { North Mayo River near Spenser, } \\
\text { VA }\end{array}$ & 270.6 & 53 & $\begin{array}{l}\text { Towanda Creek near } \\
\text { Monroeton, PA }\end{array}$ & 553.9 \\
\hline 16 & Sandy River near Danville, VA & 288.5 & 54 & Lycoming Creek near Trout & 452.7 \\
\hline 17 & Meherrin River near & 1428.7 & & Run, PA & \\
\hline & Lawrenceville, VA & & 55 & Pine Creek at Cedar Run, PA & 1557 \\
\hline 18 & $\begin{array}{r}\text { Goose Creek near } \\
\text { Huddleston, VA }\end{array}$ & 485.4 & 56 & $\begin{array}{l}\text { Sinnemahoning } \mathrm{Cr} \text { at Sterling } \\
\text { Run, PA }\end{array}$ & 705.5 \\
\hline 19 & Johns Creek at New Castle, VA & 276.1 & 57 & Brokenstraw Creek at & 784.9 \\
\hline 20 & Craig Creek at Parr, VA & 852.3 & & Youngsville, PA & \\
\hline 21 & Cowpasture River near Clifton & 1194.6 & 58 & Mill Creek near Coshocton, $\mathrm{OH}$ & 70.3 \\
\hline & Forge, VA & & 59 & Wakatomika Creek near & 363.4 \\
\hline 22 & Dunlap Creek near Covington, & 424.8 & & Frazeysburg, $\mathrm{OH}$ & \\
\hline & VA & & 60 & Manistee River near Sherman, MI & 2243.6 \\
\hline 23 & Greenbrier River at Buckeye, WV & 1365 & 61 & Big Bureau Creek at Princeton, IL & 505.1 \\
\hline 24 & Williams River at Dyer, WV & 329.7 & 62 & Edwards River near New & 1151.6 \\
\hline 25 & Rapidan River near Culpeper, VA & 1209.7 & & Boston, IL & \\
\hline 26 & Goose Creek near Leesburg, VA & 859.2 & 63 & La Moine River at Ripley, IL & 3354.6 \\
\hline 27 & Cedar Creek near Winchester, & 264 & 64 & North River at Palmyra, MO & 922.8 \\
\hline & VA & & 65 & Fox River at Wayland, MO & 1027.6 \\
\hline 28 & North Fork Shenandoah River at & 543.4 & 66 & Rapid Creek near Iowa City, IA & 65.4 \\
\hline & Cootes Store, VA & & 67 & Turkey River at Garber, IA & 3858.2 \\
\hline 29 & South Branch Potomac River NR & 1684.5 & 68 & Grant River at Burton, WI & 695.3 \\
\hline & Petersburg, WV & & 69 & Platte River near Rockville, WI & 370.8 \\
\hline 30 & Cheat River near Parsons, WV & 1856.9 & 70 & Big Eau Pleine River at & 576.3 \\
\hline 31 & Big Sandy Creek at & 517.4 & & Stratford, WI & \\
\hline & Rockville, WV & & 71 & Jump River at Sheldon, WI & 1477.3 \\
\hline 32 & Deer Creek at Rocks, MD & 244.4 & 72 & Little Fork River at Littlefork, & 4383.5 \\
\hline 33 & Sherman Creek at Shermans Dale, & 534.4 & & $\mathrm{MN}$ & \\
\hline & PA & & 73 & Whetstone River near Big Stone & 1046.8 \\
\hline 34 & Bush Kill at Shoemakers, PA & 305.9 & & City, SD & \\
\hline
\end{tabular}

TABLE 1. (Continued) 
TABLE 1. (Continued)

\begin{tabular}{|c|c|c|}
\hline Station No. & Station & $\begin{array}{l}\text { Watershed } \\
\text { area }\left(\mathrm{km}^{2}\right)\end{array}$ \\
\hline 74 & White River near Oacoma, SD & 25791 \\
\hline 75 & Soldier Creek near Topeka, KS & 748.6 \\
\hline 76 & $\begin{array}{l}\text { Stranger Creek near } \\
\text { Tonganoxie, KS }\end{array}$ & 1092.7 \\
\hline 77 & Jacks Fork at Eminence, MO & 1053.5 \\
\hline 78 & Current River at Van Buren, MO & 4349 \\
\hline 79 & Current River at Doniphan, MO & 5318.6 \\
\hline 80 & $\begin{array}{l}\text { Eleven Point River near } \\
\text { Bardley, MO }\end{array}$ & 2023.8 \\
\hline 81 & Nueces River at Laguna, TX & 1961.4 \\
\hline 82 & Frio River at Concan, TX & 1028.3 \\
\hline 83 & Gila River near Gila, NM & 4804.9 \\
\hline 84 & Pecos River near Pecos, NM & 445 \\
\hline 85 & $\begin{array}{l}\text { Gallinas Creek near Montezuma, } \\
\text { NM }\end{array}$ & 198.1 \\
\hline 86 & $\begin{array}{l}\text { Rayado Creek near Cimarron, } \\
\text { NM }\end{array}$ & 159.2 \\
\hline 87 & Rio Hondo near Valdez, NM & 96.3 \\
\hline 88 & Beaver River near Beaver, UT & 236.4 \\
\hline 89 & $\begin{array}{l}\text { Combined Flow Logan River near } \\
\text { Logan, UT }\end{array}$ & 555.6 \\
\hline 90 & $\begin{array}{l}\text { Martin Creek near Paradise } \\
\text { Valley, NV }\end{array}$ & 454.5 \\
\hline 91 & $\begin{array}{l}\text { Big Rock Creek near Valyermo, } \\
\text { CA }\end{array}$ & 59.5 \\
\hline 92 & Arroyo Seco near Pasadena, CA & 41.6 \\
\hline 93 & $\begin{array}{l}\text { Bear Creek near Lake Thomas A. } \\
\text { Edison, CA }\end{array}$ & 135.5 \\
\hline 94 & $\begin{array}{l}\text { Pitman Creek below Tamarack } \\
\text { Creek, CA }\end{array}$ & 59.8 \\
\hline 95 & $\begin{array}{r}\text { Merced River at Happy Isles } \\
\text { Bridge near Yosemite, CA }\end{array}$ & 468 \\
\hline 96 & $\begin{array}{l}\text { Merced River at Pohono Bridge } \\
\text { near Yosemite, CA }\end{array}$ & 833.1 \\
\hline 97 & $\begin{array}{l}\text { Orestimba Creek near Newman, } \\
\text { CA }\end{array}$ & 347.8 \\
\hline 98 & Mill Creek near Los Molinos, CA & 337.6 \\
\hline 99 & Deer Creek near Vina, CA & 539.8 \\
\hline 100 & Salmon River at Somes Bar, CA & 1943.1 \\
\hline 101 & $\begin{array}{l}\text { Smith River near Crescent City, } \\
\text { CA }\end{array}$ & 1578 \\
\hline 102 & $\begin{array}{l}\text { South Fork Coquille River at } \\
\text { Powers, OR }\end{array}$ & 443.1 \\
\hline 103 & $\begin{array}{l}\text { Row River above Pitcher Creek } \\
\text { near Dorena, OR }\end{array}$ & 546.8 \\
\hline 104 & Long Tom River near Noti, OR & 226.5 \\
\hline 105 & $\begin{array}{l}\text { South Santiam River below } \\
\text { Cascadia, OR }\end{array}$ & 458.2 \\
\hline 106 & $\begin{array}{l}\text { Little North Santiam River near } \\
\text { Mehama, OR }\end{array}$ & 286.8 \\
\hline 107 & Siletz River at Siletz, OR & 526.3 \\
\hline 108 & Sandy River near Marmot, OR & 674.2 \\
\hline 109 & $\begin{array}{l}\text { Little Sandy River near Bull Run, } \\
\text { OR }\end{array}$ & 59.9 \\
\hline 110 & $\begin{array}{l}\text { East Fork Lewis River near } \\
\text { Heisson, WA }\end{array}$ & 323.9 \\
\hline 111 & $\begin{array}{l}\text { Umatilla River above Meacham } \\
\text { Creek near Gibbon, OR }\end{array}$ & 341.4 \\
\hline
\end{tabular}

TABLE 1. (Continued)

\begin{tabular}{clc}
\hline Station No. & \multicolumn{1}{c}{ Station } & $\begin{array}{r}\text { Watershed } \\
\text { area }\left(\mathrm{km}^{2}\right)\end{array}$ \\
\hline 112 & Boise River near Twin Springs, ID & 2154.4 \\
113 & Trapper Creek near Oakley, ID & 133.2 \\
114 & Yellowstone River at Corwin & 6783.6 \\
& Springs, MT & \\
115 & Johnson Creek at Yellow Pine, ID & 561.9 \\
116 & Lochsa River near Lowell, ID & 3053.4 \\
117 & St. Joe River at Calder, ID & 2679 \\
118 & Satsop River near Satsop, WA & 769.9 \\
119 & North Fork Skokomish River near & 147 \\
& $\quad$ Hoodsport, WA \\
120 & Dungeness River near Sequim, & 405 \\
& $\quad$ WA & 398.4 \\
121 & Sauk River near Darrington, WA & 683.8 \\
122 & North Fork Stillaguamish River & \\
& $\quad$ near Arlington, WA & 830.6 \\
123 & Stehekin River at Stehekin, WA & 1855.3 \\
124 & Sauk River near Sauk, WA \\
125 & Thunder Creek near Newhalem, & 273.8 \\
& $\quad$ WA
\end{tabular}

that area's hydrological balance. This integrative property also provides an indirect accounting of the broad effects of the watershed's surface: that is, its vegetation, soil type, and terrain characteristics. However, gradual changes in land use and land cover over time can introduce similarly gradual and nonclimatic changes in streamflow (Graf 1977; Zhang and Schilling 2006), while the introduction of regulation, diversions, or dams can introduce regimelike shifts (Graf 2006; Villarini et al. 2009).

The purpose of the U.S. Geological Survey HydroClimatic Data Network is to provide data suitable for evaluating streamflow in a long-term climatic context. The HCDN-2009 dataset (Lins 2012) is an update of a previous HCDN dataset (HCDN-1988; Slack and Landwehr 1992) with a revised network of gauge stations. Although HCDN-1988 gauge stations were screened to exclude stations where human activities had a significant effect on the associated watershed, in 2009 a review was conducted to evaluate the existing HCDN network, remove stations that no longer met the inclusion criteria, and consider the addition of new stations (Lins 2012).

Time series of mean water-year (October-September) streamflow during 1939-2011 were derived from monthly mean flow rates from the HCDN-2009 data. The 125 gauge stations selected here (Fig. $1 \mathrm{~b}$ and Table 1 ) provide continuous records of mean streamflow during those 73 water years. The station's watershed areas vary from 31 to $25791 \mathrm{~km}^{2}$. Of the 743 current HCDN-2009 stations, these stations were also selected based on having no more than $10 \%$ estimated data during the station's entire 
period of record. The gauge stations in Fig. 1b are identified with one of five color-coded U.S. areas: the southeastern (beige), northeastern (violet), midwestern (yellow), south-central (red), western (blue), and northwestern (green) regions. Although a more uniform geographic coverage of watershed regions would be ideal, these 125 stations tend to be concentrated in the eastern and western United States. The southeastern and northeastern regions contain 57 stations, while 38 stations are located in the western and northwestern regions.

\section{c. AMO, PDO, North Atlantic, and Kaplan SSTA indices}

Calendar-year AMO values for 1896-2012 were averaged from monthly values obtained from the NOAA/ Earth Systems Research Laboratory (ESRL; http://www. esrl.noaa.gov/psd/data/timeseries/AMO/). NOAA/ESRL also calculates a corresponding monthly record of North Atlantic SST (NASST) by adding a 1951-80 North Atlantic SST climatology to the undetrended North Atlantic SSTA series. The resulting monthly NASST values were then averaged here to form water-year NASST series during 1896-2011. Yearly PDO values during 1900-2012 were averaged from the Joint Institute for the Study of the Atmosphere and Ocean monthly PDO values (http:// jisao.washington.edu/pdo/PDO.latest). The extended version 2 SSTA analysis of Kaplan et al. (1998) was used in section 4f's SSTA correlations, and to form additional annual and seasonal SSTA indices averaged over the grid regions outlined in Fig. $10 \mathrm{~b}$.

\section{The optimal ranking regime method}

The ORR method ranks the data values in a time series, samples those rankings over moving time windows, and then calculates Mann-Whitney $U$ and $Z$ statistics (Mann and Whitney 1947) for each running sample. For a specified sample size, the $U$ statistic for a sample of rankings is a normally distributed variable, with values in the lower and upper tails of a $U$ distribution indicating a high incidence of low or high rankings in a sample. Significant ranking regimes here and in Part I are determined via one of two $Z$-normalization schemes that assume either a null hypothesis of white noise variation $H_{0}$ or that the time series contains no IMD climate variation $H_{1}$. By sampling rankings over running time windows, every possible ranking sequence occurring over a fixed window duration is tested. This process is repeated using sampling windows of varying width; thus, a time series' ranking sequences are exhaustively sampled over a range of window durations. By comparing the magnitudes of the significant $Z$ statistics in all the ranking samples, the method can objectively identify a time series' most significant sequences of low or high rankings, without imposing thresholds that define low or high rankings. The details of calculating running $U$ and $Z$ statistics and $H_{0}$ null parameters and of the Monte Carlo process that calculates $H_{1}$ null parameters can be found in section 3 of Part I.

Figures $2 \mathrm{a}-\mathrm{e}$ demonstrates the ORR procedure applied to a time series of nationally averaged divisional precipitation (NPCP) for the 1896-2012 calendar years. Figure $2 \mathrm{a}$ shows the annual NPCP values, while Fig. $2 \mathrm{~b}$ shows $Z$ statistics for NPCP rankings sampled over running 10-yr time windows. The horizontal lines in Fig. $2 \mathrm{~b}$ mark negative and positive significance at two-sided $95 \%$ and $99 \%$ confidence levels and a corresponding dry shade-wet shade scheme for showing negative and positive significance at those levels. The colored horizontal lines in Fig. 2c mark the 10-yr ranking regimes shown as negatively or positively significant at a $95 \%$ or better confidence level in Fig. 2b, superimposed on the NPCP series. The vertical placement of those lines shows the ranking regime's corresponding $Z$ statistic, as measured by the figure's right-hand axis.

The ORR method extends the Fig. $2 c$ test to a wider range of time scales by calculating running $U$ and $Z$ statistics with sampling windows of varying length. In the 117-yr precipitation series, these windows varied from $n_{I}=6-45 \mathrm{yr}$, while rankings in the shorter 73-yr streamflow series were sampled over moving 6-35-yr windows. Normalizing $U$ statistics into $Z$ statistics allows for significance testing of a single window size, as in Fig. 2c, but also allows for comparing the significance of $Z$ statistics derived from varying window sizes. After the $U$ statistics from each running analysis of the NPCP series were converted into corresponding $Z$ statistics, the significant ranking regimes from all the running tests that exceeded a two-sided $95 \%$ confidence threshold are combined as in Fig. 2d. Those regimes are then screened for the most significant ranking sequences occurring over nonoverlapping time windows (Fig. 2e). A qualitative description of this iterative screening algorithm can be found in section 3 of Part I. In the Fig. 2e NPCP series, this process identified optimally significant national dry regimes during 1930-39 and 1952-67 and an optimal wet regime during 1972-2010.

The simplicity of the ORR algorithm's output-a time series' most significant, nonoverlapping ranking regimesmakes it possible to graphically identify regime patterns in the analyses of different data series. Figure $3 a$ is the 1896-2012 time series of area-weighted annual precipitation averaged over the western U.S. (WUS) climate divisions (WPCP) in Fig. 1a, with the series' optimal ranking regimes superimposed as in Fig. 2e. Figures $3 b$ and $3 \mathrm{c}$ show similar ORR results for annual precipitation 


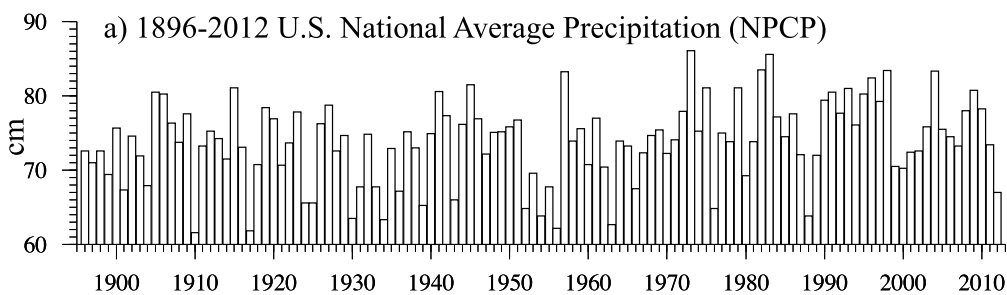

b) Running 10 Year Mann-Whitney Z Statistics of NPCP Rankings
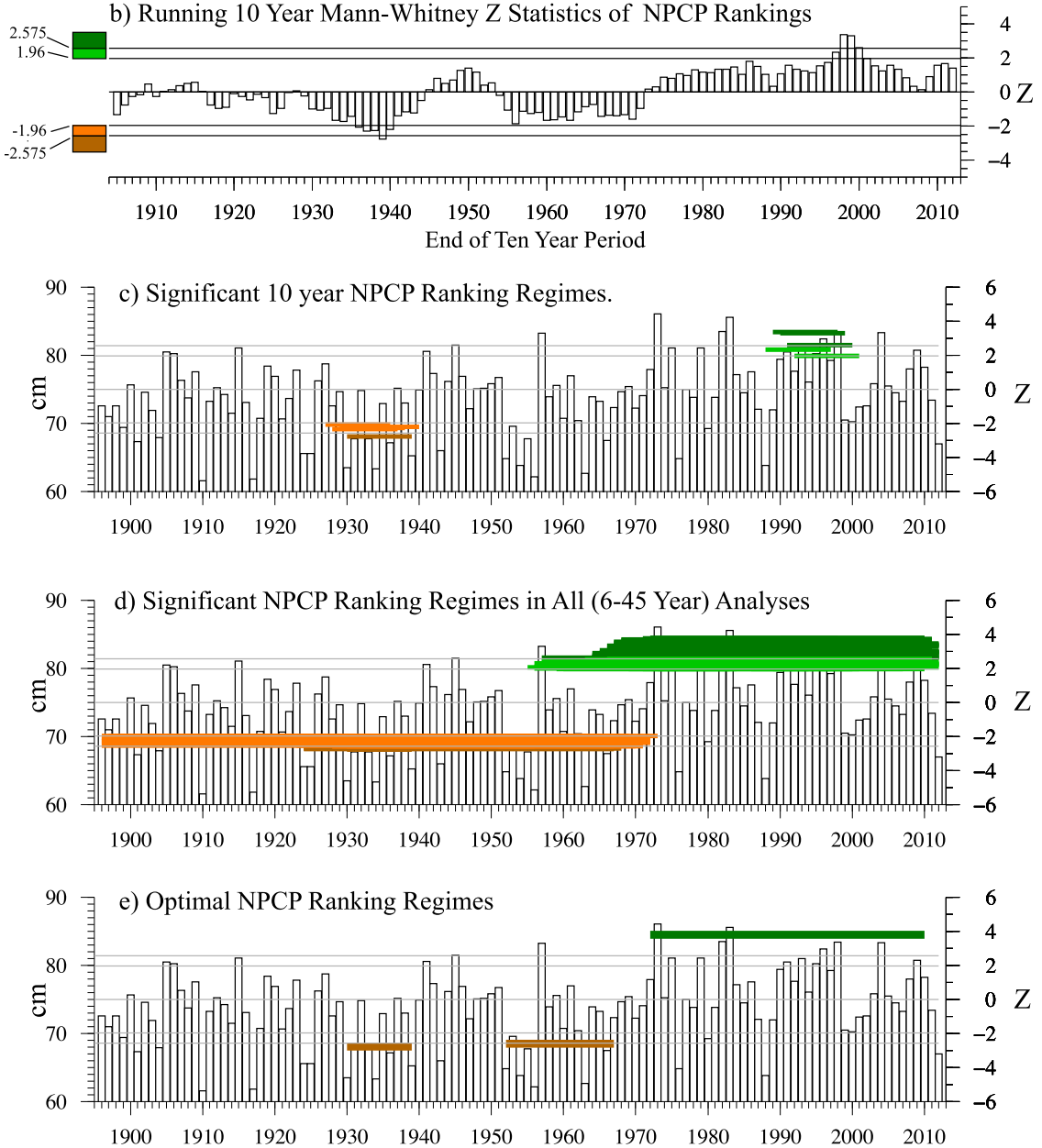

FIG. 2. (a) Time series of annual NPCP values during 1896-2012. (b) Mann-Whitney $Z$ statistics of ranked NPCP values sampled over running 10-yr time windows. Horizontal lines indicate two-sided $95 \%(Z= \pm 1.96)$ and $99 \%(Z= \pm 2.575)$ confidence intervals. (c) As in (a), but with horizontal extent of colored bars showing significant 10-yr dry and wet NPCP ranking regimes as indicated in (b). Vertical placement of bars shows corresponding $Z$ values as marked by right-hand axis. Color scheme on left-hand axis shows positive and negative significance at 95\% and 99\% confidence levels. (d) As in (c), but with significant dry and wet phase NPCP ranking regimes indicated by running Mann-Whitney $Z$ analyses with 6-, 7-, , , 45-yr sampling windows. (e) The optimally significant dry and wet phase NPCP ranking regimes in (d) occurring over nonoverlapping time windows.

series averaged over the central U.S. (CUS) and eastern U.S. (EUS) climate divisions. The EUS precipitation (EPCP) and CUS precipitation (CPCP) regime patterns resemble those of the Fig. 2e NPCP series: that is, dry regimes before 1970 and multidecadal wet regimes after that year. In contrast with the recent CUS and EUS wet periods, the most significant WUS wet regime in Fig. 3a occurred during 1906-16, a period that closely coincides with the early twentieth-century pluvial period described by Fye et al. (2003) and Cook et al. (2011). While 

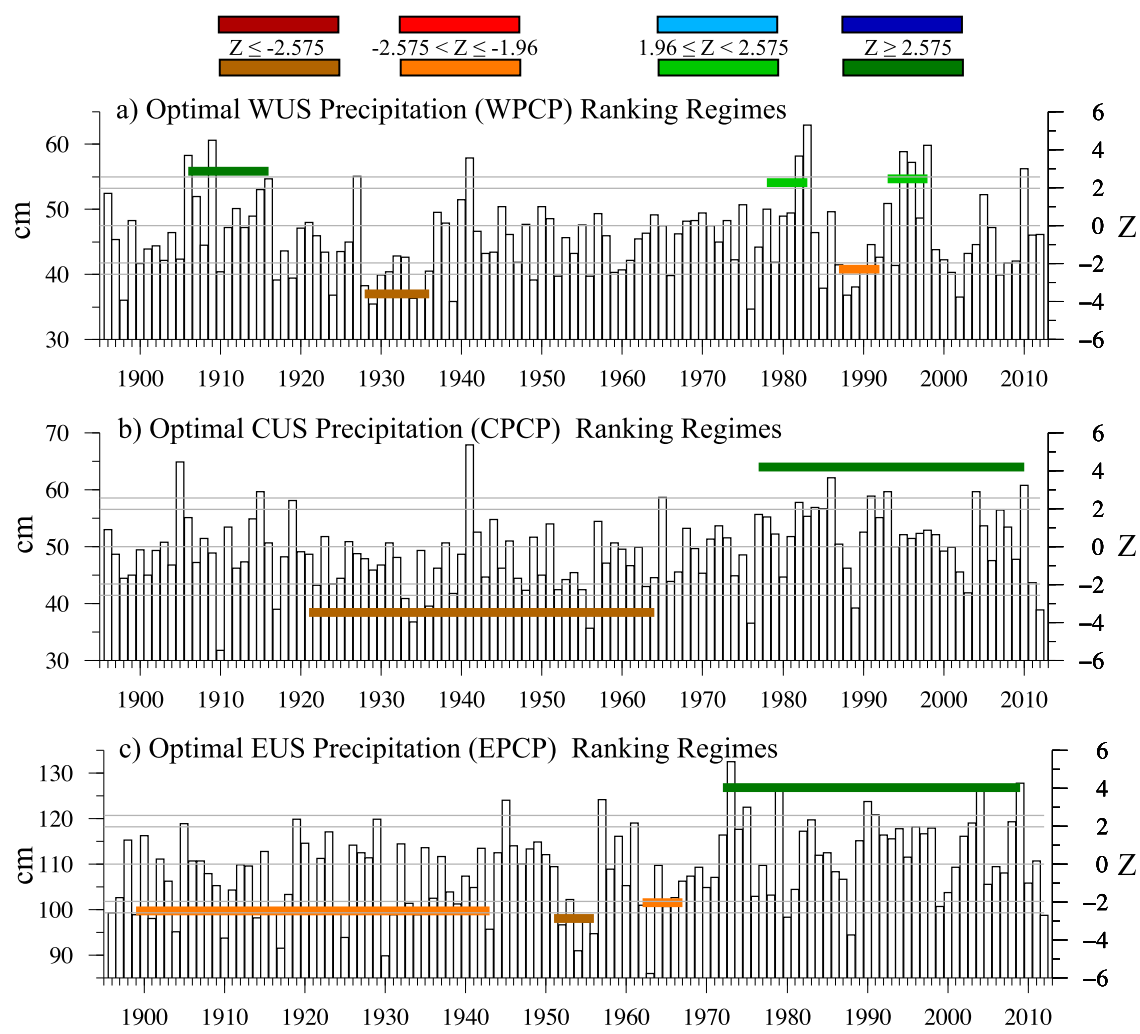

d) WPCP, CPCP, \& EPCP Dry and Wet Regime Periods

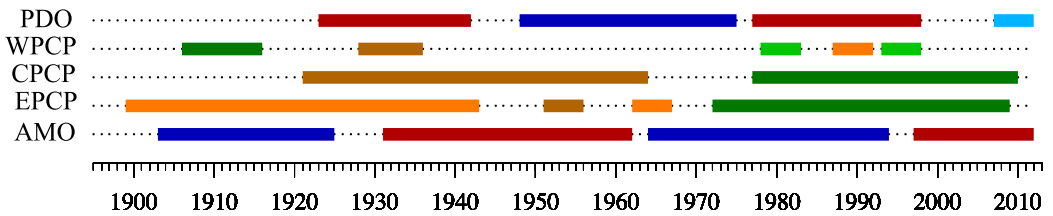

FIG. 3. (a) As in Fig. 2e, but for annual WPCP spatially averaged over the blue-shaded climate divisions in Fig. 1a. (b) As in Fig. 2e, but for annual CPCP spatially averaged over the yellow-shaded climate divisions in Fig. 1a. (c) As in Fig. 2e, but for annual EPCP spatially averaged over the green-shaded climate divisions in Fig. 1a. (d) Optimal PDO, WPCP, CPCP, EPCP, and AMO ranking regimes plotted as $Z$ lines. The dry-wet and cold-warm shading schemes for positive and negative $Z$ statistics at $95 \%$ and $99 \%$ significance levels is as found across the top.

a multidecadal pluvial was present over the CUS and EUS regions during the late twentieth century, the WUS region experienced an intradecadal precipitation cycle marked by wet conditions during 1978-83, dry conditions during 1987-92, and a return to wet conditions during 1993-98.

The ORR method detects a time series' most significant and distinct sequences of low and high rankings. If shading schemes for positive and negative significance are defined (e.g., the dry-wet and cold-warm phase schemes of Fig. 3), the resulting nonoverlapping ranking regime periods can be plotted on a single horizontal axis. These horizontal plots, referred to here and in Part I as $Z$ lines, allow for a more concise graphic comparison of results from multiple time series. The $Z$ lines from Figs. 3a-c and $Z$ lines calculated from the 1896-2012 annual AMO and 1900-2012 annual PDO series (see Figs. 1e and 2a of Part I) are plotted in Fig. 3d. As in Part I, AMO and PDO $Z$ lines are plotted with a cool and warm phase scheme that reflects temperature anomalies in the North Atlantic and along the U.S. West Coast. If the ORR procedure is applied to time series from data at different locations (e.g., the annual or seasonal precipitation for the 102 CPC climate divisions), the corresponding $Z$ lines can be arranged to display optimal ranking regimes in time and space. 


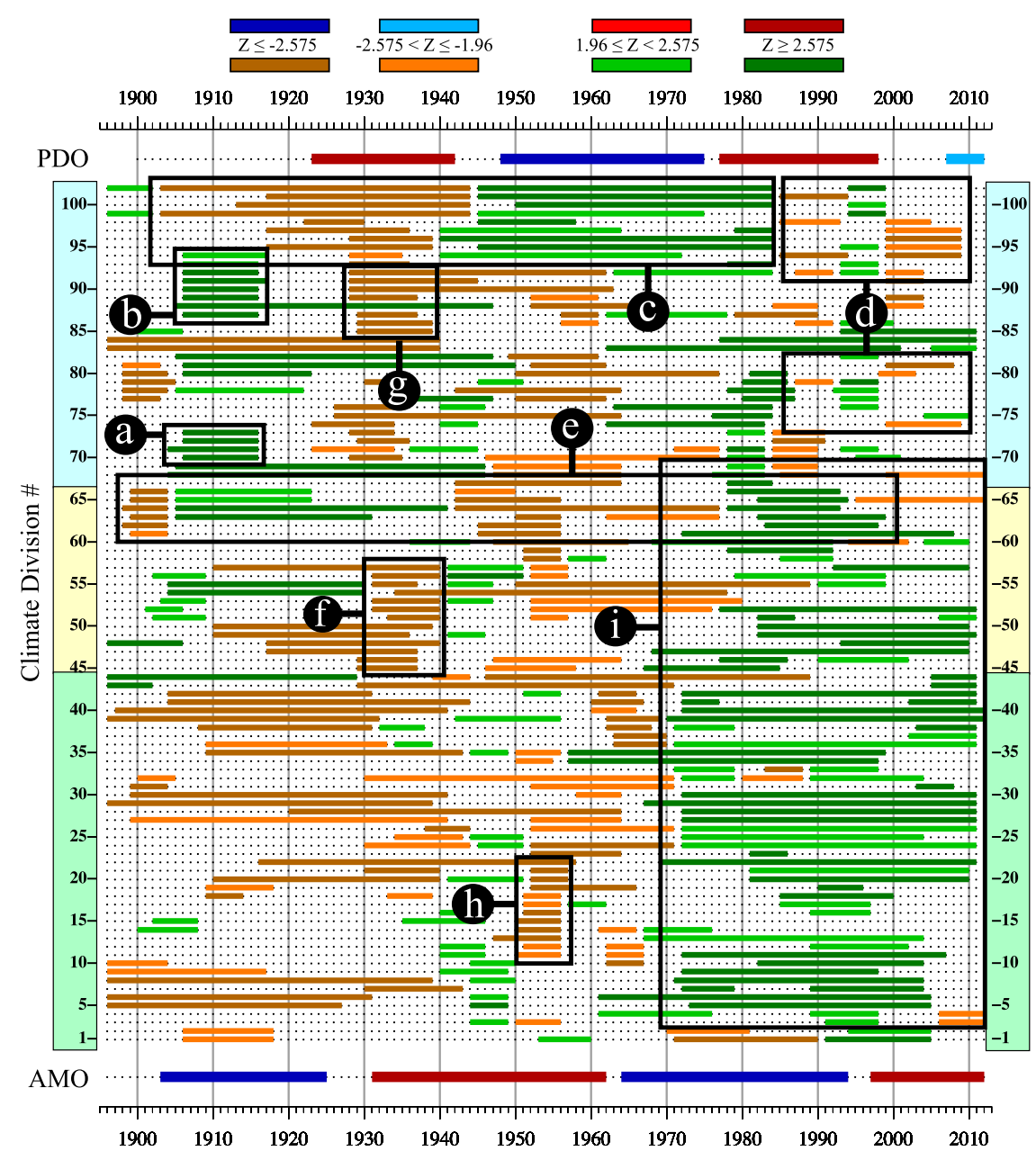

FIG. 4. The $Z$ lines for ORR in the annual precipitation time series for each of the 102 climate divisions in Fig. 1a. The vertical axis marks the corresponding climate division number. Green-, yellow-, and blue-shaded regions on vertical axis mark $Z$ lines in the EUS, CUS, and WUS regions in Fig. 1a. Positive and negative significance at $95 \%$ and $99 \%$ confidence levels is marked by the shading scheme across the top. The Fig. 3c AMO $Z$ line is shown below the EUS region climate division $Z$ lines, and the PDO $Z$ line is shown above the WUS region $Z$ lines. (a)-(i) The black frames outline the IMD precipitation regime features discussed in the text.

\section{Continental U.S. precipitation: 1896-2012}

\section{a. Annual precipitation}

Figure 4 plots the $Z$ lines from the ORR analyses of the annual precipitation series for the climate divisions in Fig. 1a. The ordering of that figure's $Z$ lines is identical to that in the Part I temperature analyses: that is, as the climate division number increases from 1 to 102 , the $Z$ lines of the EUS, CUS, and WUS regions are plotted from bottom to top. The first $Z$ line is for southern Florida (climate division 1), and $Z$ lines 2-44 show IMD regimes for climate divisions along a winding path that extends through the South, Texas, the Midwest, midAtlantic regions, and the Northeast. The CUS $Z$ lines start in Michigan's Upper Peninsula (climate division $45)$ and end in western Arizona. The WUS region's $Z$ lines begin in southern Nevada (climate division 67) and then show $Z$ lines for climate divisions along a path that continues through California, Nevada, the northern Rockies and northern plains, and the Pacific Northwest. In Figs. 4-8, the AMO and PDO $Z$ lines from Fig. 3 are also plotted below the EUS region's $Z$ lines and above the WUS region's $Z$ lines.

Figs. $4 \mathrm{a}, \mathrm{b}$ outline wet regimes in California (divisions 70-74) and the interior western United States (divisions 87 and 89-94) that coincide with the early twentiethcentury pluvial found in the WPCP average precipitation series in Fig. 3a. In Fig. $4 c$ in the Pacific 


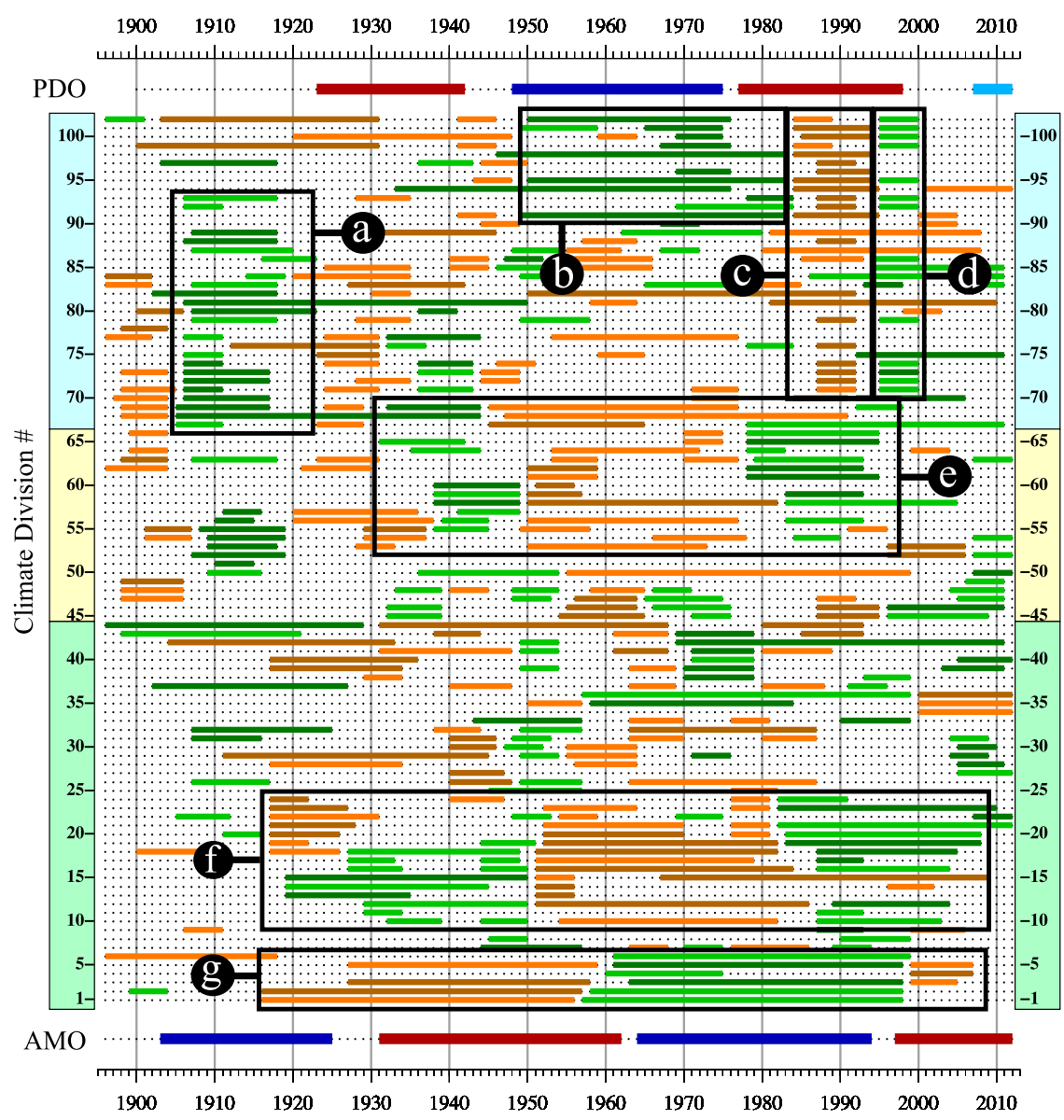

FIG. 5. As in Fig. 4, but for the ORR analyses of winter (DJF) precipitation rankings. (a)-(g) The black frames outline IMD precipitation regime features discussed in the text.

Northwest (divisions 95-102) a transition from dry to wet multidecadal conditions in the mid-1940s roughly coincides with an opposite phase shift in the PDO. However, while those climate divisions experienced relatively long-term precipitation regimes before the mid-1980s that were roughly in phase with the PDO, after that time evidence of the interdecadal precipitation cycle in Fig. 3a is apparent (Fig. 4d). Although western drought conditions after the late 1990s (Cook et al. 2004, 2007) were not found to be significant in the WPCP series, dry regimes are apparent over divisions 94-98 after 1998. This interdecadal cycle in northwestern rainfall coincides with the appearance of a western warm period in the ORR analyses of annual temperature in Part I (see their Fig. 4c).

Southwestern climate divisions 61-67 (Fig. 4e) show evidence of an irregular multidecadal precipitation cycle that, before the 1980s, is in approximate antiphase with that found in the Pacific Northwest in Fig. 4c. The dry conditions of the 1930s are apparent in the central (Fig. 4f) and northern plains (Fig. 4g), and the 1950s drought is evident in southern climate divisions (Fig. 4h). Although coherent wet regimes are rare in the EUS region before 1970, after that year Fig. 4i shows that climate in the EUS region and much of the CUS region was dominated by wet conditions.

Wet conditions over the United States in the late twentieth century have been noted by Karl et al. (1996) and also by Mauget $(2003 \mathrm{a}, 2004)$ in streamflow east of the Rockies. Wet regimes after 1970 have also been found by Pederson et al. (2013) and Seager et al. (2012) in their studies of hydrological trends in the watershed region of the New York City water supply. While Pederson et al. (2013) noted that those wetter conditions were part of a broader shift over the northeastern United States, Fig. 4i shows similar wet regimes over other areas of the EUS region. Although multidecadal wet periods are also found here in the U.S. Northeast beginning in the early 1970s (divisions 39, 40, and 42), wet regimes of similar duration that end at or near the end of the data record are also evident in areas of the Midwest 


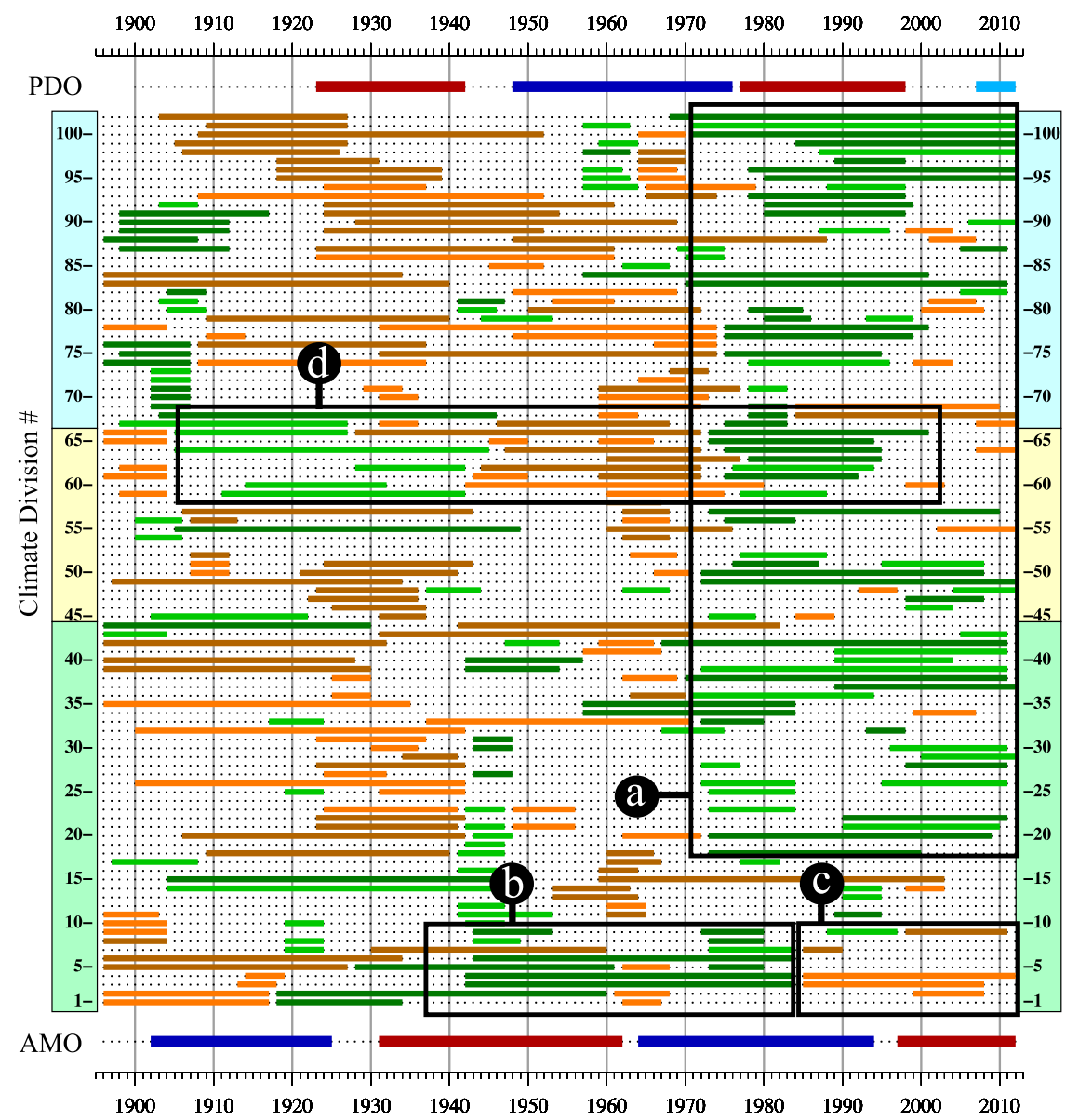

FIG. 6. As in Fig. 4, but for the ORR analyses of spring (MAM) precipitation rankings. (a)-(d) The black frames outline IMD precipitation regime features discussed in the text.

(divisions 20-22 and 24-30). Some southern climate divisions $(5,6$, and $8-11)$ have also experienced multidecadal wet periods of similar duration after 1970. However, in contrast to the recent wet regimes in northeastern and midwestern divisions, those optimal southern wet regimes have ended on or before 2005. In southeastern divisions 4 and 5, dry periods are indicated during 2006-2102.

\section{b. Winter precipitation}

The $Z$ lines in Fig. 5 are derived from winter (DJF) precipitation rankings. The AMO and PDO $Z$ lines are the same as those in Fig. 4, which are based on calendaryear rankings. In the WUS region, the early twentiethcentury pluvial conditions in Fig. 4a are also apparent in winter precipitation in Fig. 5a, although the latter's winter regimes show less spatial coherence. The Pacific Northwest experienced wet winter regimes during the 1948-76 PDO cool phase period (Fig. 5b), but over shorter periods relative to those in annual precipitation in Fig. 4c. Dry winter regimes are detected throughout most of the WUS region during the mid-1980s through the mid 1990s (Fig. 5c), which was followed by a wet period during the late 1990s (Fig. 5d). However, as measured by low DJF precipitation rankings, the most recent western drought conditions during 1998-2004 (Cook et al. 2007) are not as apparent.

In the CUS region and in southwestern climate divisions, a noisy tendency to dry winter conditions is evident between the early 1950s and mid-1970s, with a similarly noisy tendency to wet regimes before and after that time (Fig. 5e). Evidence of a similar lowfrequency cycle, roughly in phase with the PDO, is also apparent in climate divisions in the southwestern portion of the EUS region (Fig. 5f). The $Z$ lines framed in Figs. 5e,f represent a single continuous area extending across the south-central United States and the Great Plains that straddle the EUS and CUS regions. Thus, winter precipitation in these areas shows a tendency to wet and dry winter regimes that appear weakly linked to 


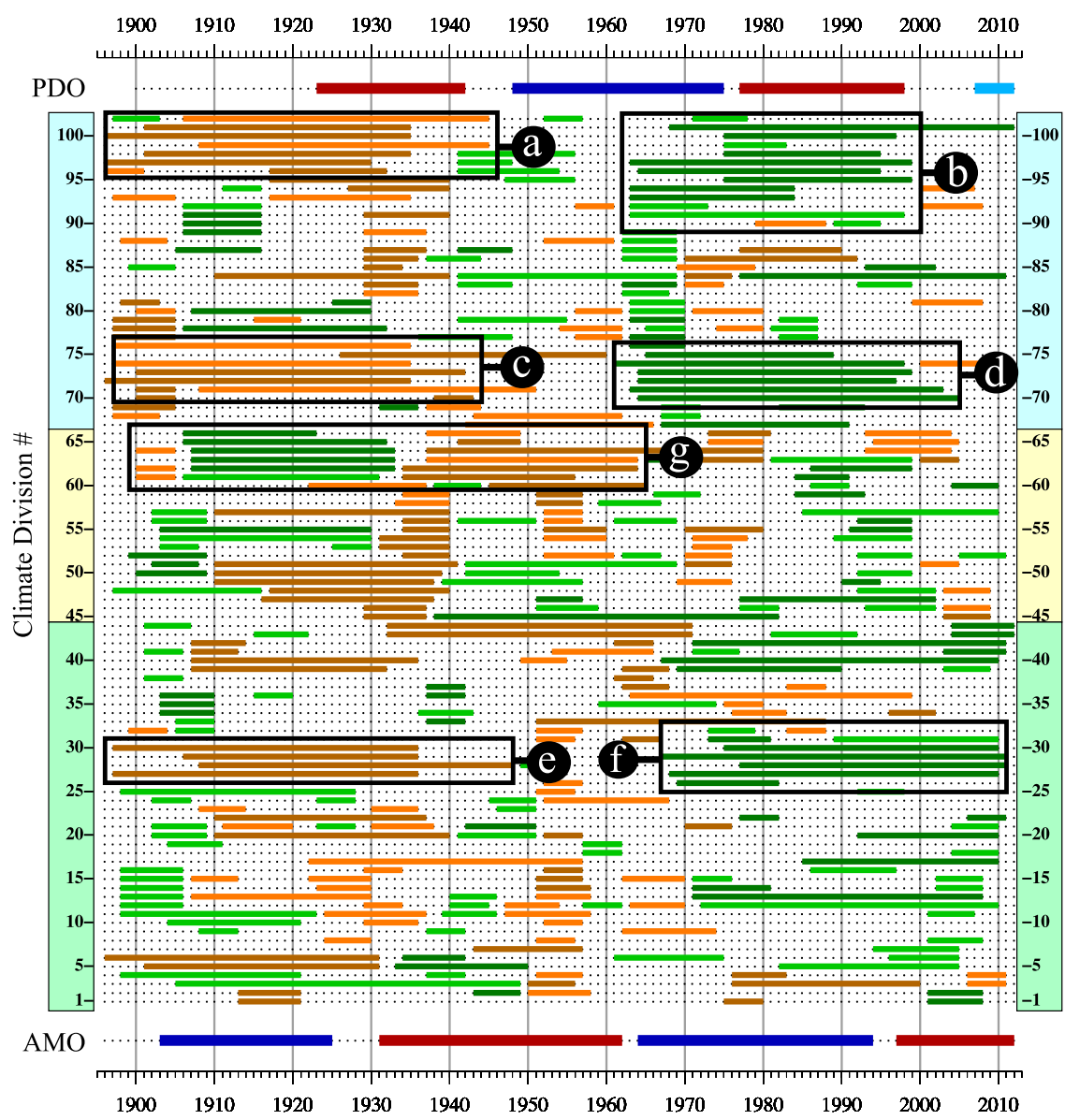

FIG. 7. As in Fig. 4, but for the ORR analyses of summer (JJA) precipitation rankings. (a)-(g) The black frames outline IMD precipitation regime features discussed in the text.

PDO phase and that are in rough counterphase to IMD variation in winter rainfall in the northwest (i.e., Figs. 5b,c). By contrast, climate divisions in Florida and the U.S. Southeast (divisions 1-6) show a pattern of multidecadal DJF precipitation regimes that are in approximate counterphase with the AMO (Fig. 5g).

\section{c. Spring precipitation}

The $Z$ lines in Fig. 6 are calculated from spring (MAM) precipitation rankings. Similar to the annual ORR analyses, Fig. 6a also shows an increased tendency to wet spring regimes after 1970. However, unlike Fig. 4, these wet periods are more evident in the WUS and CUS regions and EUS climate divisions outside of the Southeast (Fig. 6a). Although some southeastern climate divisions experienced multidecadal wet regimes before the mid1980s (Fig. 6b), after that time periods of low ranked spring precipitation are apparent in some southeastern divisions (Fig. 6c). In CUS climate divisions, a noisy multidecadal cycle in spring precipitation seems apparent (Fig. 6d), similar to that found in winter precipitation in Fig. $5 f$ but lagging the winter precipitation cycle by approximately $10 \mathrm{yr}$.

\section{d. Summer precipitation}

Like the patterns of IMD precipitation regimes found in the spring analyses, the $Z$ lines for summer U.S. rainfall (Fig. 7) seems less coherent in space and time when compared to the annual analyses (Fig. 4). In some areas, there are regime patterns that are consistent with increasing long-term trends: that is, dry regimes in the early twentieth century and wet regimes during its last decades. These include a contiguous group of western climate divisions in the Pacific Northwest (Figs. 7a,b) and California and Nevada (Figs. 7c,d) and a separate group of divisions in Michigan and the Midwest (Figs. 7e,f). Before 1970, a multidecadal period of wet summers is followed by a multidecadal dry regime in the U.S. Southwest (Fig. 7g). The wet portion of that cycle extended from 1906/07 to the early 1930s, suggesting a stronger Southwest summer monsoon during that time. 


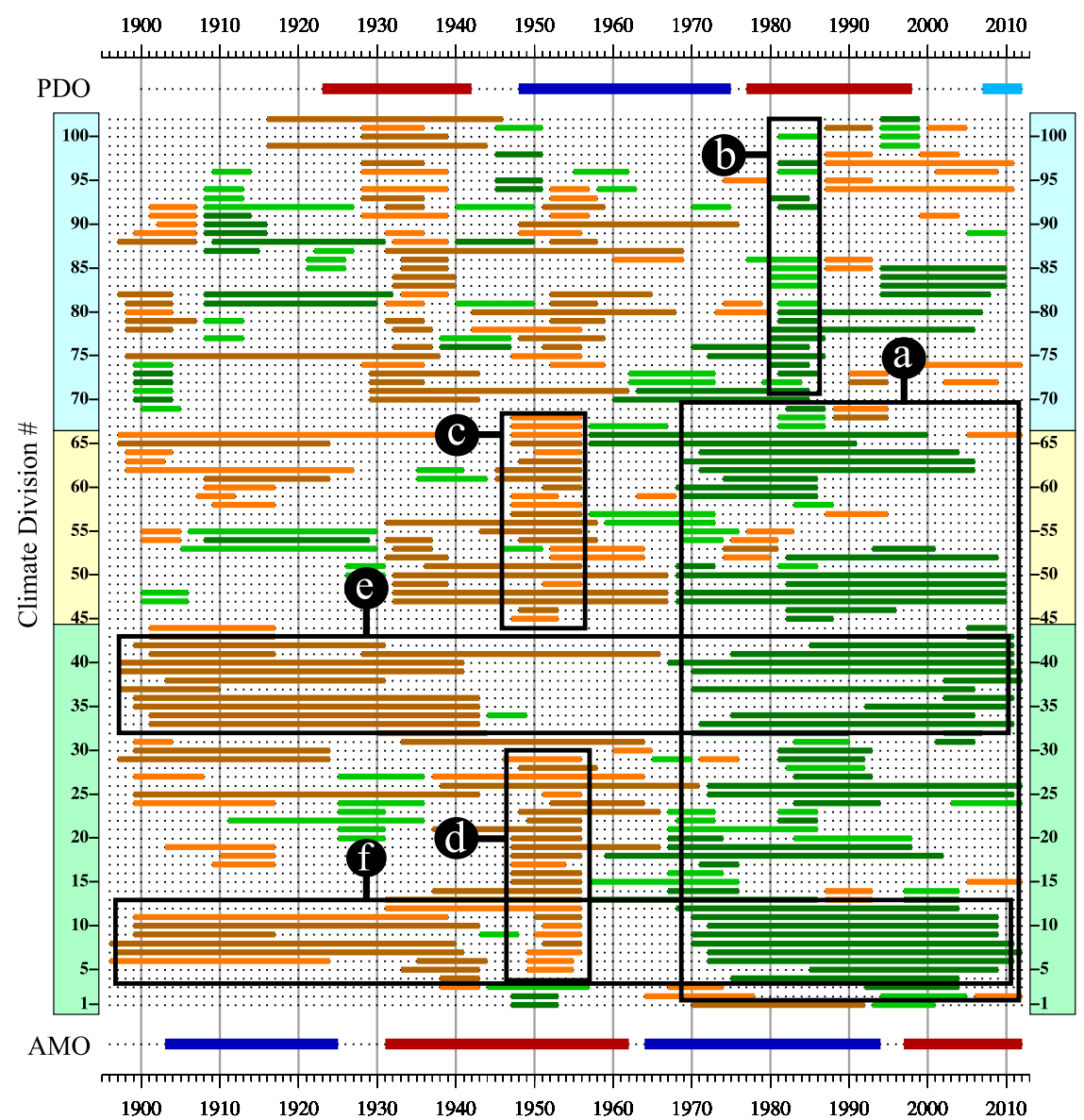

FIG. 8. As in Fig. 4, but for the ORR analyses of fall (SON) precipitation rankings. (a)-(f) The black frames outline IMD precipitation regime features discussed in the text.

\section{e. Fall precipitation}

The optimal ranking regimes derived from fall (SON) precipitation rankings are plotted in Fig. 8. In contrast to the winter, spring, and summer analyses (Figs. 5-7), the general pattern of the post-1970 pluvial in the EUS and CUS regions in annual precipitation (Fig. 4i) is also found in fall precipitation (Fig. 8a). Unlike spring precipitation after 1970 (Fig. 6a), fall wetness does not seem as evident in the WUS region. Wet fall conditions were, however, present over western climate divisions during the early 1980s (Fig. 8b), which was a period of wet conditions over the WUS region as a whole (Fig. 3c). Before 1970 dry fall regimes are evident over the CUS region (Fig. 8c) and over adjacent climate divisions in the western part of the EUS region (Fig. 8d) before and during the 1950s drought period. Similar to the longterm variability in summer rainfall in some areas in Fig. 7, the fall $Z$ lines in the U.S. Northeast (Fig. 8e) and South (Fig. 8f) have regime signatures consistent with long-term trends: that is, relatively dry periods in the early decades of the data record and wet regimes after 1970.

\section{f. Correlations of EUS precipitation versus Kaplan SSTA}

Although an intradecadal drought cycle is evident over the western United States (Figs. 3c, 4d, and 5c,d) during the 1980s and 1990s, the leading regime pattern in U.S precipitation in recent decades shows pluvial conditions that are apparent nationally (Fig. 2e) and over the CUS and EUS regions (Figs. 3a,b, 4i, and 8a) since the early 1970s. Given evidence of a multidecadal shift in precipitation over the eastern United States and the role of SST variation as a basic driver of the hydrological cycle, time series of EUS precipitation were correlated with the gridded Kaplan SSTA data.

Figures 9a-e map the Pearson correlations $\rho$ of annual- and seasonal-averaged EPCP in Fig. 1a with Kaplan SSTA averaged over the concurrent time periods during 1896-2012. Confidence thresholds for correlations at each grid location were calculated 

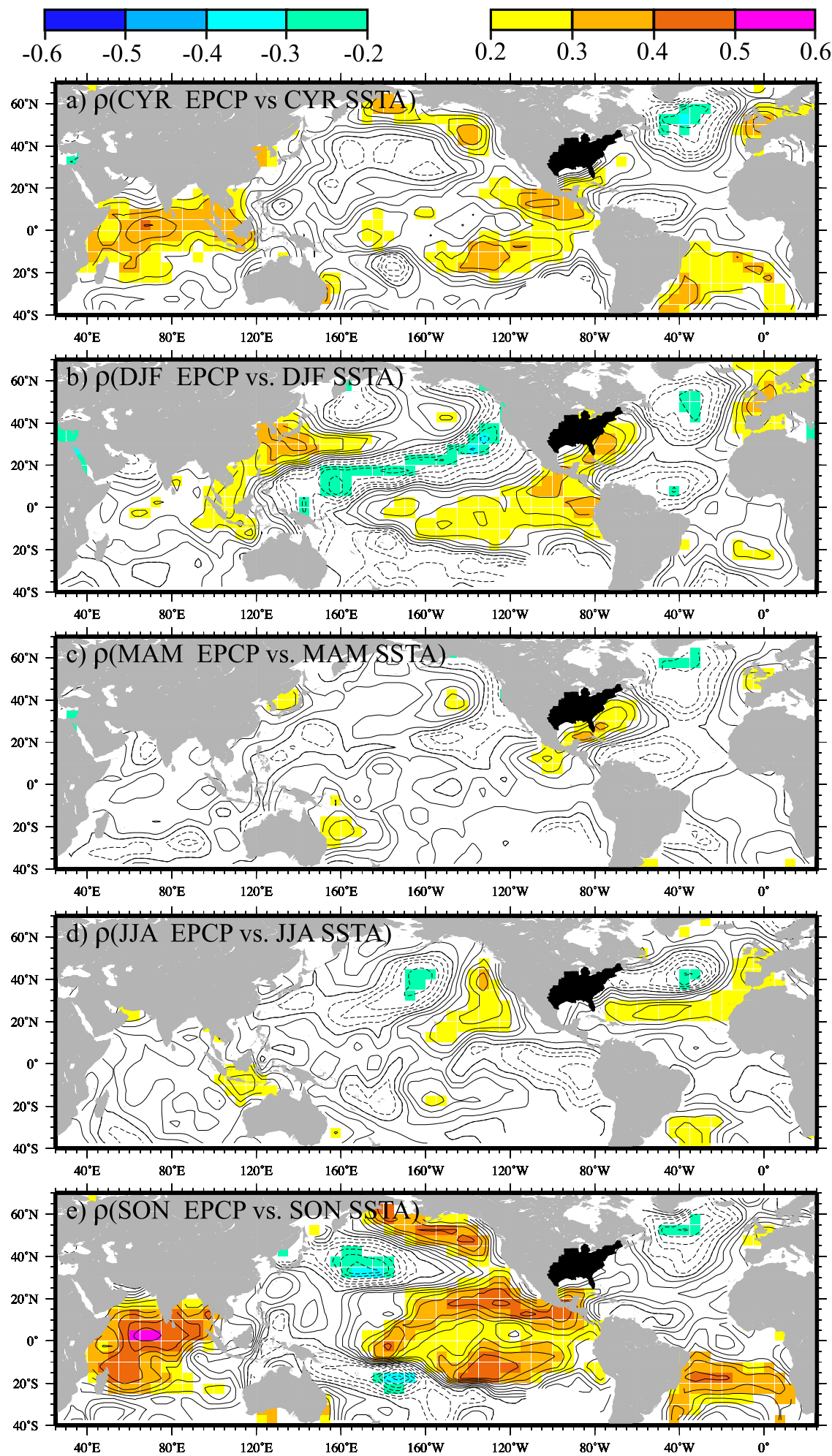

FIG. 9. (a) Pearson correlations of annual EPCP with annually averaged Kaplan extended SSTA analyses during 1896-2012. Solid (dashed) contours show positive (negative) correlations at 0.05 intervals. Shaded grid locations show correlations significant at a $95 \%$ confidence level. (b) As in (a), but for winter (DJF) EPCP correlated with average DJF SSTA. (c) As in (a), but for spring (MAM) EPCP correlated with average MAM SSTA. (d) As in (a), but for summer (JJA) EPCP correlated with average JJA SSTA. (e) As in (a), but for fall (SON) EPCP correlated with average SON SSTA. 

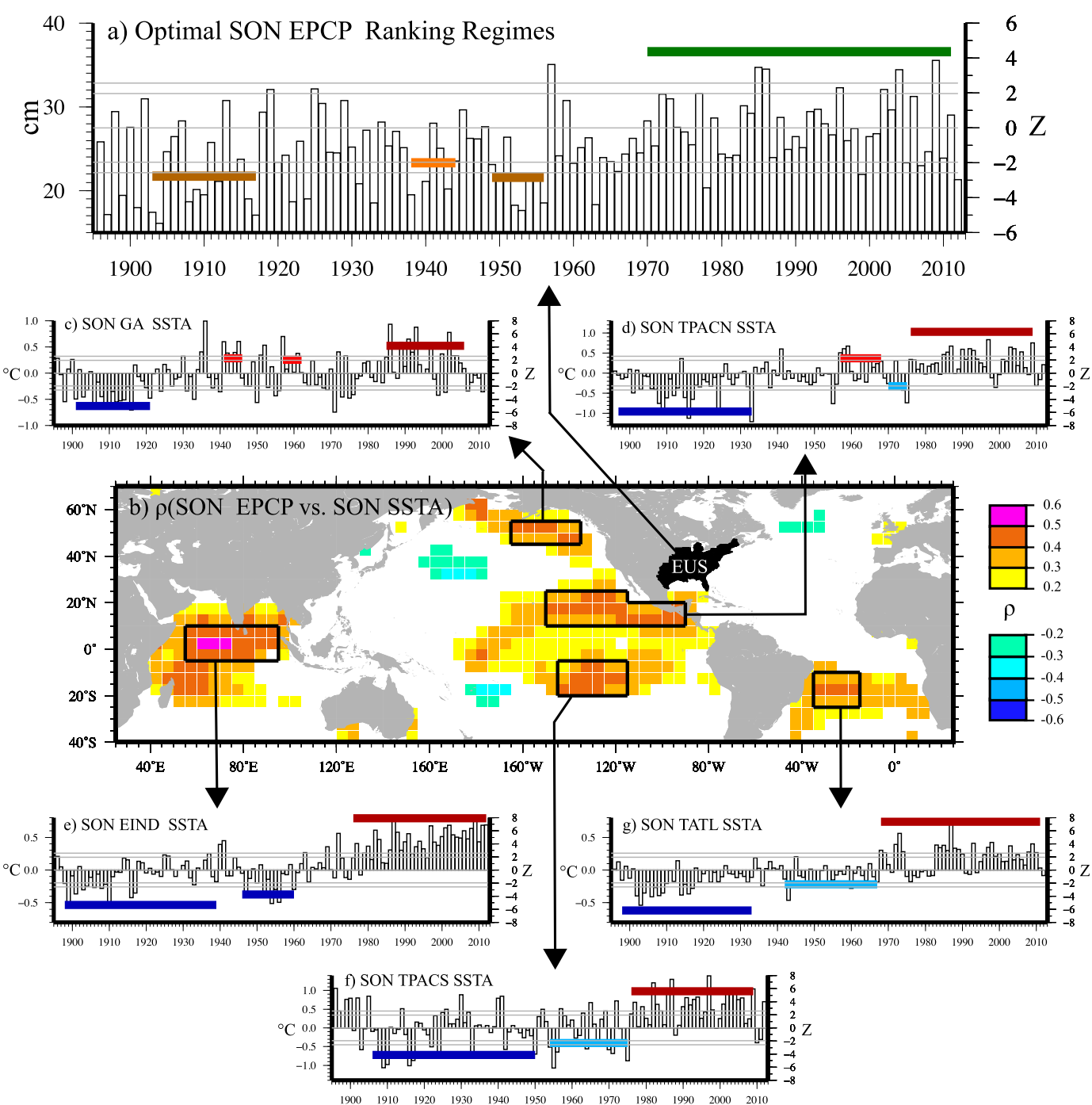

h) Optimal SON EPCP \& SSTA Ranking Regimes

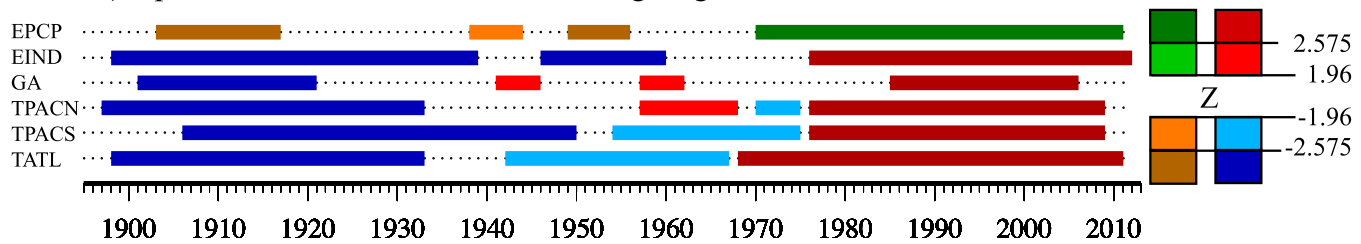

FIG. 10. (a) Fall precipitation series averaged over the EUS region [shown in (b)] with optimal wet and dry ranking regimes as plotted in Fig. 2e. (b) The significant correlations of fall EPCP with SON SSTA as in Fig. 9e. (c) SON SSTA averaged over the GA grid region in (b) with optimal cool and warm SSTA ranking regimes. (d) As in (c), but for SON SSTA over the TPACN grid region in (b). (e) As in (c), but for SON SSTA over the EIND grid region in (b). (f) As in (c), but for SON SSTA over the TPACS grid region in (b). (g) As in (c), but for SON SSTA over the TATL grid region in (b). (h) The optimal precipitation and SSTA ranking regimes in (a) and (c)-(f) plotted as $Z$ lines.

using the noise modeling method of Ebisuzaki (1997). This approach calculated the EPCP series' Fourier transform and then constructed 117-yr noise series from the resulting Fourier amplitudes and randomized phase values. A thousand of these noise series were then correlated with each SSTA series to form null $\rho$ distributions at each $5^{\circ} \times 5^{\circ}$ grid location. The shaded correlations in Fig. 9 are considered significant because they exceed a two-sided $95 \%$ confidence level. 
The correlation of the annual EPCP series in Fig. 3a with annually averaged SSTA (Fig. 9a) show significant positive $\rho$ values in the equatorial Indian Ocean, the Gulf of Alaska, the tropical eastern Pacific, and the tropical Atlantic. The correlations of DJF EPCP with DJF SSTA in Fig. 9b show an alternating pattern of correlations in the North Pacific, with positive correlations in the northwestern and tropical eastern Pacific, separated by a band of weak negative correlations spanning the North Pacific from southwest to northeast. Winter EPCP is also positively correlated with DJF SSTA off the U.S. East Coast. Spring (MAM) EPCP is similarly correlated with coastal Atlantic and eastern equatorial Pacific SSTA (Fig. 9c) but over more limited areas and at generally lower levels than those found in the DJF correlations. The summer EPCP versus summer SSTA correlations (Fig. 9d) show similar but weak $(|\rho|<0.3)$ correlation dipole patterns in the North Pacific and North Atlantic. The pattern of fall correlations (Fig. 9e) is similar to the annual correlations (Fig. 9a), but the SON correlations are more extensive in the tropical eastern Pacific and have clearly stronger magnitudes $(\rho>0.4)$. The correlation of SON SSTA with fall precipitation averaged over the EUS region exceeds 0.5 at some grid locations in the equatorial Indian Ocean.

Evidence of a fall precipitation teleconnection pattern similar to that in Fig. 9e was found by Seager et al. (2012) when they correlated seasonal precipitation averaged over New York State's Catskill region $\left(41^{\circ}-43^{\circ} \mathrm{N}, 73.5^{\circ}-\right.$ $76^{\circ} \mathrm{W}$ ) with SSTA data. Although derived from a lowpass filtered precipitation time series, their seasonal SSTA correlation patterns (i.e., their Figs. 6a-d) also show a clear emergence of significant correlations with tropical SSTA during the fall. However, while their SON Catskills precipitation series correlated significantly with SSTA in the tropical Indian and Atlantic Oceans, significant correlations like those in the tropical east Pacific in Fig. 9e were not apparent.

Figure 10a shows the EPCP series for SON precipitation, together with its optimal ranking regimes, as in Fig. 2e. Figure 10b repeats the Fig. 9e fall SSTA correlation pattern and outlines five grid regions where SON SSTA was found to correlate significantly with the 1896-2012 SON EPCP series. Figures 10c-g show the SON SSTA series averaged over those five regions and the corresponding optimal ranking regimes plotted with the cool shade-warm shade scheme illustrated to the right of Fig. 10h. The five centers of action in Fig. 10b include a Gulf of Alaska (GA) region (Fig. 10c), a tropical North Pacific (TPACN) region (Fig. 10d), an equatorial Indian Ocean (EIND) region (Fig. 10e), a tropical South Pacific (TPACS) region (Fig. 10f), and a tropical Atlantic (TATL) region (Fig. 10g). Figure 10h plots the
$Z$ lines for the Fig. 10a EPCP regimes and the SSTA regimes in Figs. 10c-g. The Fig. 10h regime patterns are consistent with the emergence of warm SSTA over those ocean regions and wet fall conditions over the eastern United States after 1970. Counterpart figures for Fig. 10h formed from the ORR analysis of data from the winter, spring, and summer seasons (Fig. S1 of the supplemental material) show that, although the recent SST warming is also present in those seasons, corresponding eastern wet regimes like that in Fig. 10a are not evident. As a result, the ORR analyses (of Fig. 10h and Fig. S1), as well as the correlation patterns in Fig. 9, indicate a fall season teleconnection between warming SST and increasing precipitation over the eastern United States after 1970.

\section{HCDN-2009 streamflow: 1939-2011}

Figure 11 plots the results of the ORR analyses of average water-year streamflow rankings for each of the HCDN-2009 gauge stations in Fig. 1b. The ordering of the $125 Z$ lines roughly follows that of the precipitation $Z$ lines in Figs. 4-8. Stations $1-31$ are in the beige U.S. Southeast and mid-Atlantic region in Fig. 1b. Stations 32-57 are in the violet northeastern region, while stations $58-80$ are in the yellow midwestern region. Stations $81-87$ are located in the red south-central region. Stations 88-101 are in the blue western region, while stations $102-125$ are located in the green northwestern region. As in Figs. 4-8, an AMO $Z$ line is plotted below the southeastern region's $Z$ lines and a PDO $Z$ line is plotted above the northwestern region $Z$ lines. However, the AMO and PDO $Z$ lines in Fig. 11 differ slightly from those in Figs. 4-8, because the former were calculated from the AMO and PDO rankings during the 1939-2011 streamflow analysis period. Thus, for example, the recent 2007-12 PDO high phase period in the 113-yr ranking analysis was not significant at a 95\% confidence level in the 73-yr analysis of Fig. 11. Otherwise, the AMO and PDO $Z$ lines defined in the precipitation and streamflow analyses are qualitatively similar.

In Fig. 11a, low-ranked-flow conditions at stations 13-57 during the 1960s mark the location and period of the 1960s mid-Atlantic and northeastern drought (Namias 1967; Nigam et al. 1999; Barlow et al. 2001). In the early 1970s, many of these stations saw a transition to high-flow regimes (Fig. 11b). A similar shift in streamflow around 1970 has been noted by McCabe and Wolock (2002) in the eastern United States, by Armstrong et al. (2013) in the northeastern United States, and by Anctil and Coulibaly (2004) in southern Quebec. Although this eastern streamflow transition 


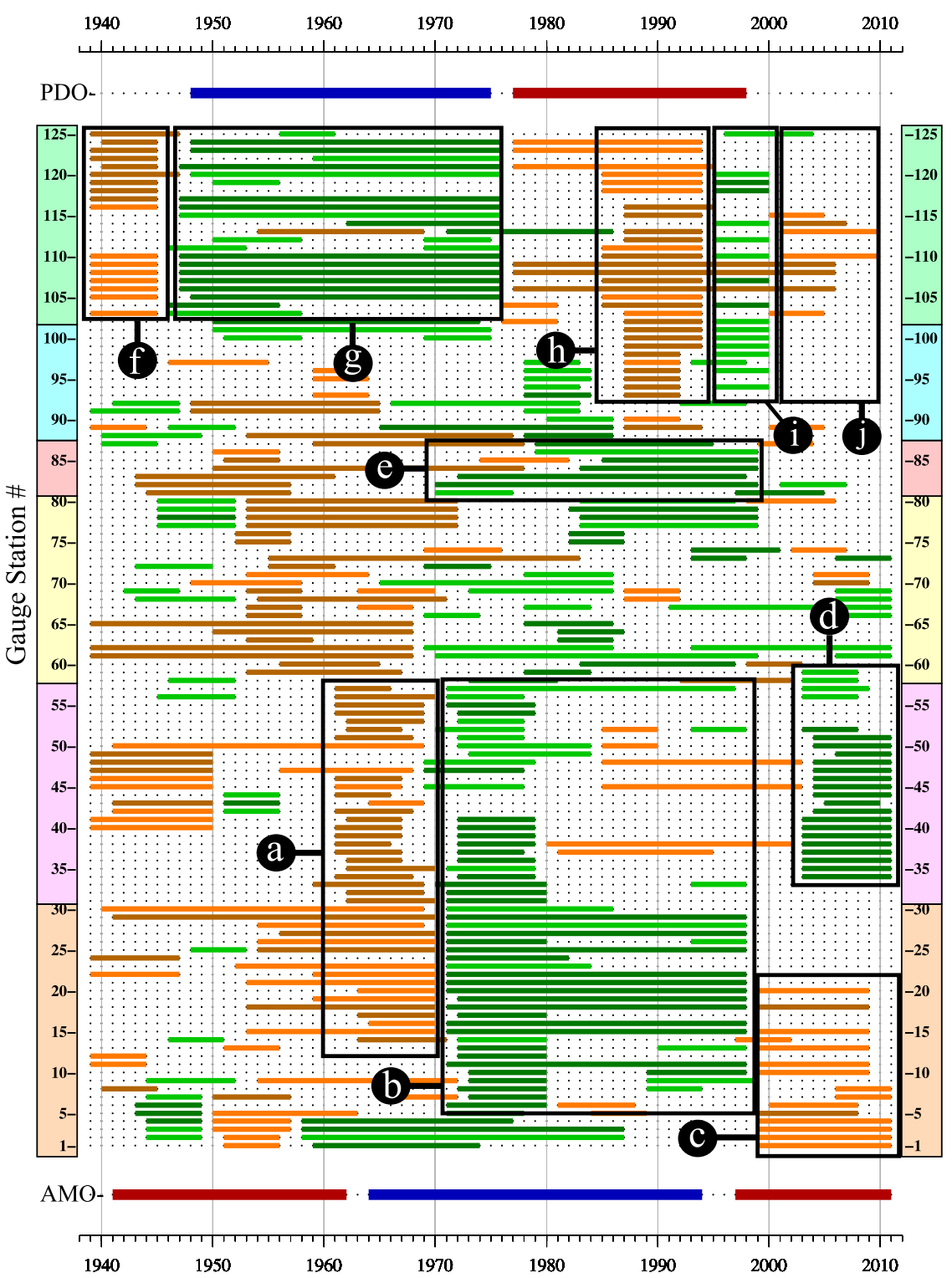

FIG. 11. The $Z$ lines for ORR in the water-year mean streamflow time series for each of the 125 HCDN-2009 gauge stations in Fig. 1b. The vertical axis marks the corresponding station number in Fig. 1b. Color-coded regions on the vertical axis mark $Z$ lines in the corresponding shaded regions in Fig. 1b. Positive and negative significance at $95 \%$ and $99 \%$ confidence levels is marked by the $Z$ shading scheme across the top of Fig. 4. The AMO $Z$ line calculated from the 1939-2011 rankings is shown below the southeastern region (beige) $Z$ lines, and the PDO $Z$ line is shown above the northwestern region (green) $Z$ lines. (a)-(j) The black frames outline the IMD streamflow regime features discussed in the text.

clearly lagged the shift in AMO phase in 1964, the 1970s were a period of extreme cold phase AMO conditions (see Fig. 1c of Part I) and relatively cold NASST conditions. Figure 12 shows the optimal ranking regimes for the NOAA/ESRL undetrended NASST series for the 1896-2011 water years. Although 1902-25 was a prolonged period of cool NASST, 1971-78 was also a significantly cool period, despite the presence of a long-term positive trend. Thus, many of the eastern high streamflow periods in Fig. 11b coincided with a period of relatively cold and fresh (Dickson et al. 1988) North Atlantic Ocean conditions. However, while many of those high-flow regimes ended in the late 1970s, some Virginia and West Virginia watersheds (e.g., stations 11, 15, 16, 18-23, 25, and 27-29) experienced high-flow periods that continued until the late 1990s. 


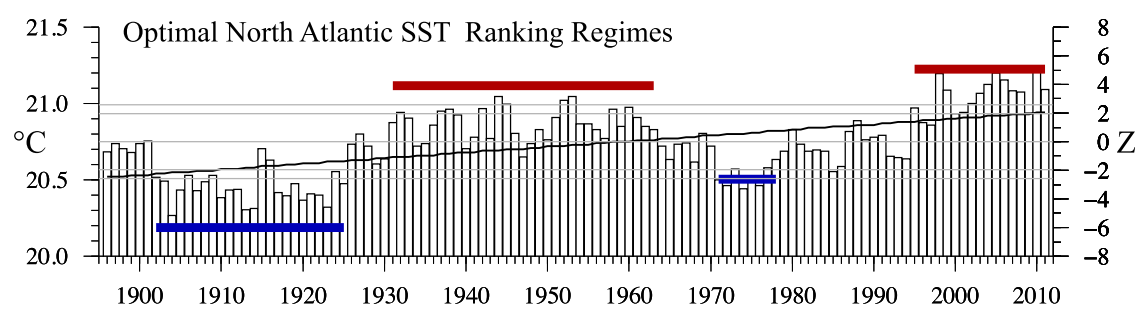

FIG. 12. Time series of water-year averaged NOAA/ESRL NASST values during 1896-2012, with optimal cool and warm ranking regimes as plotted in Fig. 2e. The solid black line shows the linear least squares fit trend.

After the 1998 shift to AMO warm phase conditions, patterns of low- and high-flow regimes are evident in the southeastern (Fig. 11c) and northeastern United States (Fig. 11d). These opposing eastern flow regimes indirectly suggest a shift in the Bermuda high-North Atlantic subtropical high ( $\mathrm{Li}$ et al. 2011), although a similarly clear shift in annual precipitation regimes is not evident over the corresponding climate divisions in Fig. 4i. Their timing also suggests an AMO influence, although there is no evidence of similar behavior during the AMO warm phase period before 1963. However, as seen in Fig. 12, the AMO represents a detrended record of North Atlantic SSTA. Thus, the flow regimes in Figs. 11c,d may possibly reflect the combined impact of the long-term upward trend in NASST in addition to the post-1998 positive AMO phase.

In the midwestern region (stations 58-80), periods of high streamflow are the exception before 1970 but more common after 1970. However, this regime shift is not as well defined as that found in Figs. 11a,b in the midAtlantic and northeastern regions. Earlier work using the ORR approach (Mauget 2003a, 2004) showed clearer evidence of multidecadal high-flow regimes in the midwestern regions after the earlier 1970s that is not as apparent in the stations in the midwestern region in Fig. 1b. This may be due to changes in gauge stations in this area that were included in the HCDN-1988 network but are not found in HCDN-2009. For example, Mauget (2003a) evaluated 12 gauge stations in Ohio, Indiana, and Illinois (OH-IN-IL), with 7 stations showing significant multidecadal high-flow periods beginning in the early 1970s and ending in the late 1990s. In the current HCDN-2009 network in Fig. 1b there are five stations in those three states that meet the criteria outlined in section 2b: none of which is included in the OH-IN-IL stations of Mauget (2003a). Of the five OH-IN-IL stations in Fig. 11, only one (station 61) experienced a continuous multidecadal high-flow period between the early 1970 s and the late 1990s.

Although high-flow periods were present in all the south-central streamflow records during 1970-2000, most of those periods ended on or before 1999 (Fig. 11e). In the Pacific Northwest (stations 102-125), streamflow regimes show, relative to the annual precipitation analyses in Fig. 4c, a clearer antiphase relationship with the PDO. Before 1945, low-flow periods were common (Fig. 11f), whereas during the 1948-76 low phase PDO period most watershed areas experienced multidecadal high-flow conditions (Fig. 11g). After 1976, low-flow regimes resumed in some northwestern gauge stations (e.g., 106, 108, 109, 114, 121, 123, and 124), while others saw the development of low-ranked-flow periods during the late 1980s and early 1990s (Fig. 11h). The latter lowflow conditions are also apparent in streamflow records 93-101, which marks the California drought conditions at that time (Bell and Basist 1994). The mid-1990s saw a shift to high-flow conditions over California and the Pacific Northwest (Fig. 11i), after which low-flow regimes (Fig. 11j) returned after 2000 at some northwestern gauge stations (e.g., stations 103 and 112-115). The most recent period of western drought during 1998-2004 (Piechota et al. 2004; Seager 2007), although apparent in annual precipitation in the Pacific Northwest (Fig. 4d), is not as clearly evident as the previous western drought regime during the late 1980s and early 1990s (Fig. 11h). Even so, the western intradecadal precipitation cycle seen in the annual (Fig. 4d) and winter (Figs. 5c,d) rainfall analyses and more clearly in annual precipitation averaged over the WUS region in Fig. 1a (Fig. 3a) is also evident in northwestern U.S. streamflow in Figs. 11h-j.

\section{Summary and discussion}

The optimal ranking regime (ORR) method was used to detect intradecadal to multidecadal (IMD) variation in U.S. climate division precipitation during 1896-2012 and average water-year streamflow during 1939-2011. In Part I, this approach was applied to annual and seasonal climate division temperature data during 1896-2012. By calculating Mann-Whitney $U$ and $Z$ statistics from data rankings sampled over moving time windows of varying 
duration, the ORR method can identify the most significant and nonoverlapping ranking sequences in a time series of climate data (e.g., Fig. 2). When optimal regimes from different locations are graphically arranged as "concise $Z$ lines" (e.g., Fig. 3d), patterns of IMD climate variation can be identified in space and time (Figs. 4-8, 11). Given the possible influence of North Atlantic and North Pacific low-frequency climate modes, the $Z$ lines for streamflow and U.S. divisional precipitation were compared with ORR-derived regimes in the Atlantic multidecadal oscillation (AMO) and the Pacific decadal oscillation (PDO). As eastern pluvial conditions after 1970 were one of the clearest IMD signals in U.S. precipitation found here, time series of annual and seasonal precipitation averaged over the eastern United States were also correlated with gridded SSTA analyses during 1896-2012. Other IMD regime patterns found in U.S. precipitation and streamflow include the following:

- An interdecadal drought cycle evident in precipitation (Figs. 3a, 4d, and 5c,d) and streamflow (Figs. 11h-j) over the western United States during the 1980s and 1990s.

- An antiphase relationship between the PDO and annual precipitation regimes in the Pacific Northwest before 1980 (Fig. 4c) that is more clearly apparent in streamflow (Figs. 11f,g).

- A shift from low to high decadal streamflow regimes in the eastern United States during the early 1970s (Figs. 11a,b) that coincided with a transition to extreme negative phase AMO conditions (Fig. 1c of Part I) and relatively cold North Atlantic SST during the 1970s (Fig. 12).

- Evidence that post-1970 wetness in the central and eastern U.S regions in Fig. 1a was most apparent in annual (Fig. 4i) and fall (SON) precipitation (Fig. 8a).

The correlations of annual and seasonal precipitation averaged over eastern climate divisions with SSTA data show significant and relatively extensive positive correlations between warming SST and increasing fall precipitation (Figs. 9f, 10). As discussed in section 4f, Seager et al. (2012) showed a similar correlation between a fall Catskills region precipitation series and tropical Atlantic and Indian Ocean SSTA during 19012007. However, because their significant fall correlations were only apparent when the Catskills series was lowpass filtered, they concluded that those precipitation correlations with tropical SSTA were most likely coincidental and not due to a causal link with interannual tropical variability. The eastern U.S. fall precipitation series in Fig. 10a, although averaged over the much larger EUS region in Fig. 10b, was not low-passed filtered. As a result, the correlation patterns in Figs. 9e and $10 \mathrm{~b}$ reflect significant positive interannual correlations between warming SST and fall precipitation averaged over the eastern United States. Seager et al. (2012) also propose, based on the ensemble means of SST-forced model simulations that failed to reproduce the 1960s northeastern drought or the subsequent wet period, that the recent Catskills pluvial is due to internal atmospheric processes. The model evaluations of Sheffield et al. (2013) also show that a multimodel mean of 17 SST-forced models from phase 5 of the Coupled Model Intercomparison Project (CMIP5) failed to reproduce observed twentieth-century wetting trends over a broader eastern U.S. region. Seager et al. (2012), however, qualify their conclusion as being valid only if the models are correct. Although such ensemble means might reproduce the pattern of U.S. precipitation teleconnections, they also underestimate the magnitude of the response (Langenbrunner and Neelin 2013). Dai (2006) notes that models underestimate precipitation intensity over the storm tracks around the U.S. East Coast and that improvements in simulating precipitation are needed in coupled climate models. Thus, the inability of models to reproduce a possible forced regional precipitation teleconnection may be a shortcoming of the models and not a sure indication of internal variability. Of course, significant correlations of eastern U.S. fall precipitation with tropical SST records that probably reflect forced warming trends (Hegerl et al. 2007; Bindoff et al. 2014) do not prove the existence of a causal teleconnection related to that warming. Even so, the potentially predictable nature of anthropogenic SST warming, as well as the correlations of Fig. 9e, suggests the potential for a continuing fall wet regime over the eastern United States.

Karl et al. (1996) associate an increase in a composite U.S. climate extremes index during the 1970s with changes in atmospheric circulation associated with the 1976 PDO shift (Trenberth 1990; Trenberth and Hurrell 1994). The correlations of the SON EPCP series in Fig. 10a with SON SSTA series in the Gulf of Alaska (GA) and tropical North Pacific (TPACN) grid regions in Fig. 10b, as well as the close coincidence of the onset of the recent eastern fall wet regime with that of warm SSTA regimes over those ocean areas (Fig. 10h), seems consistent with a PDO teleconnection. However, the transition to high eastern streamflow regimes in Fig. 11b during the early 1970s precedes the mid1970s PDO shift. National and eastern wet conditions also preceded that shift, as the wettest year in NPCP (Fig. 2a) and EPCP (Fig. 3a) precipitation series during 1896-2012 was 1973. Here, high 1970s eastern 
streamflow regimes are circumstantially associated with relatively cold North Atlantic boundary conditions during 1971-78 (Fig. 12). A link between a shift to increased streamflow and changing North Atlantic conditions might be found in the analyses of Chang and $\mathrm{Fu}$ (2002), who noted a sharp transition to strengthened North Atlantic and North Pacific storm tracks in reanalysis data around 1972/73. Later work verifying this shift in radiosonde data (Harnik and Chang 2003) found that, although some features of that shift were attributable to reanalysis biases, both the radiosonde and reanalysis data showed increased storm track intensity over the United States, the eastern Atlantic, and Europe during 1971-74. As a result, even though Fig. 9 shows no significant North Atlantic correlations, it seems possible that cooling oceanic boundary conditions over that region may have influenced that circulation shift and played a role in the early stages of the post-1970 wet regime over the eastern United States.

A broad theme in the recent national climate assessment of Walsh et al. (2014) is that effects related to increasing greenhouse gas (GHG) concentrations have been evident over the United States for decades, although in some areas the effects of natural variability are also apparent. In some respects the results presented here and in Part I are consistent with this general view. The trend toward increasing fall precipitation over the eastern United States-indicated here in SON wet regimes after 1970 (Fig. 8a) - is correlated with upper ocean warming trends that have been linked to anthropogenic forcing with a relatively high degree of certainty in attribution studies (Bindoff et al. 2014). However, as noted above, the early stages of this eastern wet regime also seem to be circumstantially linked to AMO variation. In Part I, warm western U.S. temperature regimes after the mid-1980s are roughly coincident with the recent warm Northern Hemisphere temperature (NHT) regime. Western U.S. divisional temperature series were found to be strongly correlated ( $\rho>0.6)$ with annual and summer NHT series in some areas of the interior western United States during 1896-2012 (Part I, Figs. 11k,n). As both Hegerl et al. (2007) and Bindoff et al. (2014) have concluded that GHG effects have likely contributed to surface warming over all the inhabited continents since 1950, this indicates that the initial effects of that warming over the United States have been most evident in the west. In contrast to the more trendlike regime patterns found in the ORR analyses of western temperature series in Part I, the analyses for eastern climate divisions reveal multidecadal cyclic variation that is particularly clear in annual (Part I, Fig. 4a) and winter (Part I, Fig. 6b) temperature. Although this cycle's variation generally tracks that of the AMO, before 1998 eastern temperature regimes tend to precede those of the AMO, which is inconsistent with the idea that climate variation over land regions tends to be driven by climate variation over nearby ocean regions. That phase discrepancy, as well as the abrupt onset of a cold regime in eastern temperature during the late 1950s that is associated here with the beginning of the U.S. warming hole period (Pan et al. 2004; Kunkel et al. 2006), suggests that IMD temperature variation over the eastern United States after 1950 may have been driven by a combination of factors unrelated to rising GHG concentrations. Thus, it would appear that the initial temperature effects of anthropogenic climate change over the United States are evident in the west after the mid-1980s, while internal mechanisms-with the AMO as a possible leading influence-seem to dominate in the east. Although the correlation of increasing SSTA with eastern U.S. precipitation trends does not constitute formal attribution, the initial precipitation effects of GHG-related climate change may be most evident in the east during the fall season after 1970. A western interdecadal drought cycle evident in precipitation (Figs. 3a, 4d, and 5c,d) and streamflow (Figs. 11h-j) during the recent western warm period also suggests the possible effects of rising GHG levels on hydrology in the west. However, the pluvial effect of cold phase PDO conditions on annual precipitation (Fig. 4c) and streamflow (Figs. 11g,h) in the northwest also suggests that those ocean conditions might act to mitigate drought effects.

Acknowledgments. Monthly AMO values were derived from NOAA ERSST.v3 data provided by the NOAA/Earth System Research Laboratory (Physical Sciences Division), Boulder, Colorado (http://www.esrl. noaa.gov/psd/). All figures were produced using Generic Mapping Tools (Wessel and Smith 1995). The USDA is an equal opportunity provider and employer.

\section{REFERENCES}

Anctil, F., and P. Coulibaly, 2004: Wavelet analysis of the interannual variability in southern Québec streamflow. J. Climate, 17, 163-173, doi:10.1175/1520-0442(2004)017<0163: WAOTIV $>2.0 . \mathrm{CO} ; 2$.

Armstrong, W. H., M. J. Collins, and N. P. Snyder, 2013: Hydroclimatic flood trends in the northeastern United States and linkages with large-scale atmospheric circulation patterns. Hydrol. Sci. J., 6, 197-219, doi:10.1080/02626667.2013.862339.

Barbosa, S. M., 2011: Testing for deterministic trends in global sea surface temperature. J. Climate, 24, 2516-2522, doi:10.1175/ 2010JCLI3877.1.

Barlow, M., S. Nigam, and E. H. Berbery, 2001: ENSO, Pacific decadal variability, and U.S. summertime precipitation, 
drought, and stream flow. J. Climate, 14, 2105-2110, doi:10.1175/1520-0442(2001)014<2105:EPDVAU>2.0.CO;2.

Bell, G. D., and A. N. Basist, 1994: The global climate of December 1992-February 1993. Part I: Warm ENSO conditions continue in the tropical Pacific; California drought abates. J. Climate, 7,1581-1605, doi:10.1175/1520-0442(1994)007<1581: TGCODP $>2.0 . C O ; 2$.

Bindoff, N. L., and Coauthors, 2014: Detection and attribution of climate change: From global to regional. Climate Change 2013. The Physical Science Basis, T. F. Stocker et al., Eds., Cambridge University Press, 867-952.

Chang, E. K. M., and Y. Fu, 2002: Interdecadal variations in Northern Hemisphere winter storm track intensity. J. Climate, 15, 642-658, doi:10.1175/1520-0442(2002)015<0642:IVINHW>2.0.CO;2.

Chapman, W. L., and J. E. Walsh, 2007: A synthesis of Antarctic temperatures. J. Climate, 20, 4096-4117, doi:10.1175/JCLI4236.1.

Cook, B. I., R. Seager, and R. L. Miller, 2011: On the causes and dynamics of the early twentieth-century North American pluvial. J. Climate, 24, 5043-5060, doi:10.1175/2011JCLI4201.1.

Cook, E. R., C. A. Woodhouse, C. M. Eakin, D. M. Meko, and D. W. Stahle, 2004: Long-term aridity changes in the western United States. Science, 306, 1015-1018, doi:10.1126/science.1102586.

_, R. Seager, M. A. Cane, and D. W. Stahle, 2007: North American drought: Reconstructions, causes, and consequences. Earth-Sci. Rev., 81, 93-134, doi:10.1016/j.earscirev.2006.12.002.

Cordero, E., W. Kessomkiat, J. Abatzoglou, and S. Mauget, 2011: The identification of distinct patterns in California temperature trends. Climatic Change, 108, 357-382, doi:10.1007/ s10584-011-0023-y.

Dai, A., 2006: Precipitation characteristics in eighteen coupled climate models. J. Climate, 19, 4605-4630, doi:10.1175/JCLI3884.1. , 2013: The influence of the inter-decadal Pacific oscillation on US precipitation during 1923-2010. Climate Dyn., 41, 633-646, doi:10.1007/s00382-012-1446-5.

Dickson, R. R., J. Meincke, S.-A. Malmberg, and A. J. Lee, 1988: The "Great Salinity Anomaly" in the northern North Atlantic 1968-1982. Prog. Oceanogr., 20, 103-151, doi:10.1016/ 0079-6611(88)90049-3.

Ebisuzaki, W., 1997: A method to estimate the statistical significance of a correlation when the data are serially correlated. J. Climate, 10, 2147-2153, doi:10.1175/1520-0442(1997)010<2147: AMTETS $>2.0 . \mathrm{CO} ; 2$.

Enfield, D. B., A. M. Mestas-Nunez, and P. J. Trimble, 2001: The Atlantic multidecadal oscillation and its relation to rainfall and river flows in the continental U.S. Geophys. Res. Lett., 28, 2077-2080, doi:10.1029/2000GL012745.

Fye, F. K., D. W. Stahle, and E. R. Cook, 2003: Paleoclimatic analogs to twentieth-century moisture regimes across the United States. Bull. Amer. Meteor. Soc., 84, 901-909, doi:10.1175/ BAMS-84-7-901.

Gershunov, A., and T. P. Barnett, 1998: Interdecadal modulation of ENSO teleconnections. Bull. Amer. Meteor. Soc., 79, 27152725, doi:10.1175/1520-0477(1998)079<2715:IMOET>2.0.CO;2.

Graf, W. L., 1977: Network characteristics in suburbanizing streams. Water Resour. Res., 13, 459-463, doi:10.1029/ WR013i002p00459.

- 2006: Downstream hydrologic and geomorphic effects of large dams on American rivers. Geomorphology, 79, 336-360, doi:10.1016/j.geomorph.2006.06.022.

Groisman, P. Ya., and D. R. Easterling, 1994: Precipitation changes over the northern hemispheric extratropics during the last hundred years. Global Precipitations and Climate Change, M. Desbois and F. Désalmand, Eds., 119-133.
, R. W. Knight, and T. R. Karl, 2001: Heavy precipitation and high streamflow in the contiguous United States: Trends in the twentieth century. Bull. Amer. Meteor. Soc., 82, 219-246, doi:10.1175/1520-0477(2001)082<0219:HPAHSI >2.3.CO;2.

Guttman, N. B., and R. G. Quayle, 1996: A historical perspective of U.S. climate divisions. Bull. Amer. Meteor. Soc., 77, 293-303, doi:10.1175/1520-0477(1996)077<0293:AHPOUC>2.0.CO;2.

Harnik, N., and E. K. M. Chang, 2003: Storm track variations as seen in radiosonde observations and reanalysis data. J. Climate, 16, 480-495, doi:10.1175/1520-0442(2003)016<0480: STVASI $>2.0 . \mathrm{CO} ; 2$.

Hartmann, B., and G. Wendler, 2005: The significance of the 1976 Pacific climate shift in the climatology of Alaska. J. Climate, 18, 4824-4839, doi:10.1175/JCLI3532.1.

Hartmann, D. L., and Coauthors, 2014: Observations: Atmosphere and surface. Climate Change 2013: The Physical Science Basis, T. F. Stocker et al., Eds., Cambridge University Press, $159-254$.

Hegerl, G. C., and Coauthors, 2007: Understanding and attributing climate change. Climate Change 2007: The Physical Science Basis, S. Solomon et al., Eds., Cambridge University Press, 663-745.

Hodgkins, G. A., and R. W. Dudley, 2011: Historical summer base flow and stormflow trends for New England rivers. Water Resour. Res., 47, W07528, doi:10.1029/2010WR009109.

Hoerling, M., J. Eischeid, and J. Perlwitz, 2010: Regional precipitation trends: Distinguishing natural variability from anthropogenic forcing. J. Climate, 23, 2131-2145, doi:10.1175/ 2009JCLI3420.1.

Kaplan, A., M. A. Cane, Y. Kushnir, A. C. Clement, M. B. Blumenthal, and B. Rajagopalan, 1998: Analyses of global sea surface temperature 1856-1991. J. Geophys. Res., 103, 18567-18589, doi:10.1029/97JC01736.

Karl, T. R., R. W. Knight, D. R. Easterling, and R. G. Quayle, 1996: Indices of climate change for the United States. Bull. Amer. Meteor. Soc., 77, 279-292, doi:10.1175/1520-0477(1996)077<0279: IOCCFT $>2.0 . C O ; 2$.

,$- \ldots$, and B. Baker, 2000: The record breaking global temperatures of 1997 and 1998: Evidence for an increase in the rate of global warming? Geophys. Res. Lett., 27, 719-722, doi:10.1029/1999GL010877.

Kochendorfer, J. P., and J. A. Hubbart, 2010: The roles of precipitation increases and rural land-use changes in streamflow trends in the Upper Mississippi River basin. Earth Interact., 14, doi:10.1175/2010EI316.1.

Kumar, S., J. Kinter, P. A. Dirmeyer, Z. Pan, and J. Adams, 2013: Multidecadal climate variability and the "warming hole" in North America: Results from CMIP5 twentieth- and twentyfirst-century climate simulations. J. Climate, 26, 3511-3527, doi:10.1175/JCLI-D-12-00535.1.

Kunkel, K. E., X.-Z. Liang, J. Zhu, and Y. Lin, 2006: Can CGCMs simulate the twentieth-century "warming hole" in the central United States? J. Climate, 19, 4137-4153, doi:10.1175/JCLI3848.1.

Langenbrunner, B., and J. D. Neelin, 2013: Analyzing ENSO teleconnections in CMIP models as a measure of model fidelity in simulating precipitation. J. Climate, 26, 4431-4446, doi:10.1175/JCLI-D-12-00542.1.

Lettenmaier, D. P., E. F. Wood, and J. R. Wallis, 1994: Hydroclimatological trends in the continental United States, 1948-88. J. Climate, 7, 586-607, doi:10.1175/1520-0442(1994)007<0586: HCTITC $>2.0 . C O ; 2$.

Li, W., L. Li, R. Fu, Y. Deng, and H. Wang, 2011: Changes to the North Atlantic subtropical high and its role in the 
intensification of summer rainfall variability in the southeastern United States. J. Climate, 24, 1499-1506, doi:10.1175/ 2010JCLI3829.1.

Liebmann, B., R. M. Dole, C. Jones, I. Bladé, and D. Allured, 2010: Influence of choice of time period on global surface temperature trend estimates. Bull. Amer. Meteor. Soc., 91, 1485-1491, doi:10.1175/2010BAMS3030.1.

Lins, H. F., 2012: USGS Hydro-Climatic Data Network 2009 (HCDN-2009). U.S. Geological Survey Fact Sheet 2012-3047, 4 pp.

— , and T. A. Cohn, 2011: Stationarity: Wanted dead or alive? J. Amer. Water Resour. Assoc., 47, 475-480, doi:10.1111/ j.1752-1688.2011.00542.x.

Mann, H. B., and D. R. Whitney, 1947: On a test of whether one of two random variables is stochastically larger than the other. Ann. Math. Stat., 18, 50-60, doi:10.1214/aoms/1177730491.

Mantua, N. J., S. R. Hare, Y. Zhang, J. M. Wallace, and R. C. Francis, 1997: A Pacific interdecadal climate oscillation with impacts on salmon production. Bull. Amer. Meteor. Soc., 78, 1069-1079, doi:10.1175/1520-0477(1997)078<1069: APICOW $>2.0 . \mathrm{CO} ; 2$.

Mass, C., A. Skalenakis, and M. Warner, 2011: Extreme precipitation over the west coast of North America: Is there a trend? J. Hydrometeor., 12, 310-318, doi:10.1175/ 2010JHM1341.1.

Mauget, S., 2003a: Multidecadal regime shifts in U.S. streamflow, precipitation, and temperature at the end of the twentieth century. J. Climate, 16, 3905-3916, doi:10.1175/ 1520-0442(2003)016<3905:MRSIUS > 2.0.CO;2.

- 2003b: Intra- to multidecadal climate variability over the continental United States: 1932-99. J. Climate, 16, 2215-2231, doi:10.1175/2751.1.

- 2004: Low frequency streamflow regimes over the central United States: 1939-1998. Climatic Change, 63, 121-144, doi:10.1023/B:CLIM.0000018502.86522.57.

_ 2006: Intra- to multi-decadal terrestrial precipitation regimes at the end of the 20th century. Climatic Change, 78, 317-340, doi:10.1007/s10584-006-9129-z.

— of intra- to multidecadal U.S. climate variability. Part I: Temperature. J. Climate, 27, 9006-9026, doi:10.1175/ JCLI-D-14-00040.1.

McCabe, G. J., and D. M. Wolock, 2002: A step increase in streamflow in the conterminous United States. Geophys. Res. Lett., 29, 2185, doi:10.1029/2002GL015999.

_- M. A. Palecki, and J. L. Betancourt, 2004: Pacific and Atlantic Ocean influences on multidecadal drought frequency in the United States. Proc. Natl. Acad. Sci. USA, 101, 4136-4141, doi:10.1073/pnas.0306738101.

_ J. L. Betancourt, S. T. Gray, M. A. Palecki, and H. G. Hidalgo, 2008: Associations of multi-decadal sea-surface temperature variability with US drought. Quat. Int., 188, 31-40, doi:10.1016/ j.quaint.2007.07.001.

Miranda, P. A., and A. Tomé, 2009: Spatial structure of the evolution of surface temperature (1951-2004). Climatic Change, 93, 269-284, doi:10.1007/s10584-008-9540-8.

Namias, J., 1967: Further studies of drought over northeastern United States. Mon. Wea. Rev., 95, 497-508, doi:10.1175/ 1520-0493(1967)095<0497:FSODON>2.3.CO;2.

Nigam, S., M. Barlow, and E. H. Berbery, 1999: Analysis links Pacific decadal variability to drought and streamflow in United States. Eos, Trans. Amer. Geophys. Union, 80, 621628, doi:10.1029/99EO00412.
Pan, Z., R. W. Arritt, E. S. Takle, W. J. Gutowski, C. J. Anderson, and M. Segal, 2004: Altered hydrologic feedback in a warming climate introduces a "warming hole." Geophys. Res. Lett., 31, L17109, doi:10.1029/2004GL020528.

Pederson, N., A. R. Bell, E. R. Cook, U. Lall, N. Devineni, R. Seager, K. Eggleston, and K. P. Vranes, 2013: Is an epic pluvial masking the water insecurity of the greater New York City region? J. Climate, 26, 1339-1354, doi:10.1175/ JCLI-D-11-00723.1.

Peterson, T. C., and Coauthors, 2013: Monitoring and understanding changes in heat waves, cold waves, floods and droughts in the United States: State of knowledge. Bull. Amer. Meteor. Soc., 94, 821-834, doi:10.1175/BAMS-D-12-00066.1.

Piechota, T., J. Timilsena, G. Tootle, and H. Hidalgo, 2004: The western U.S. drought: How bad is it? Eos, Trans. Amer. Geophys. Union, 85, 301-304, doi:10.1029/2004EO320001.

Reiter, E. R., and D. R. Westhoff, 1982: Linear trends in Northern Hemisphere tropospheric geopotential height and temperature patterns. J. Atmos. Sci., 39, 528-541, doi:10.1175/ 1520-0469(1982)039<0528:LTINHT>2.0.CO;2.

Roden, G. I., 1962: On sea-surface temperature, cloudiness and wind variations in the tropical Atlantic. J. Atmos. Sci., 19, 66-80, doi:10.1175/1520-0469(1962)019<0066: OSSTCA $>2.0 . \mathrm{CO} ; 2$.

Seager, R., 2007: The turn of the century North American drought: Global context, dynamics, and past analogs. J. Climate, 20, 5527-5552, doi:10.1175/2007JCLI1529.1.

_ N. Pederson, Y. Kushnir, J. Nakamura, and S. Jurburg, 2012: The 1960s drought and the subsequent shift to a wetter climate in the Catskill Mountains region of the New York City watershed. J. Climate, 25, 6721-6742, doi:10.1175/ JCLI-D-11-00518.1.

Sheffield, J., and Coauthors, 2013: North American climate in CMIP5 experiments. Part II: Evaluation of historical simulations of intraseasonal to decadal variability. J. Climate, 26, 9247-9290, doi:10.1175/JCLI-D-12-00593.1.

Slack, J. R., and J. M. Landwehr, 1992: Hydro-Climatic Data Network (HCDN): A U.S. Geological Survey streamflow data set for the United States for the study of climate variations, 1874-1988. USGS Open-File Rep. 92-129, 193 pp.

Spar, J., and P. Ronberg, 1968: Note on an apparent trend in annual precipitation at New York City. Mon. Wea. Rev., 96, 169-171, doi:10.1175/1520-0493(1968)096<0169: NOAATI $>2.0 . \mathrm{CO} ; 2$.

Sutton, R. T., and D. L. R. Hodson, 2005: Atlantic Ocean forcing of North American and European summer climate. Science, 309, 115-118, doi:10.1126/science.1109496.

— , and — 2007: Climate response to basin-scale warming and cooling of the North Atlantic Ocean. J. Climate, 20, 891-907, doi:10.1175/JCLI4038.1.

Trenberth, K. E., 1990: Recent observed interdecadal climate changes in the Northern Hemisphere. Bull. Amer. Meteor. Soc., 71, 988-993, doi:10.1175/1520-0477(1990)071<0988: ROICCI $>2.0 . \mathrm{CO} ; 2$.

_ tions in the Pacific. Climate Dyn., 9, 303-319, doi:10.1007/ BF00204745.

— climate change. Climate Change 2007: The Physical Science Basis, S. Solomon et al., Eds., Cambridge University Press, 235-336.

Villarini, G., F. Serinaldi, J. A. Smith, and W. F. Krajewski, 2009: On the stationarity of annual flood peaks in the continental 
United States during the 20th century. Water Resour. Res., 45, W08417, doi:10.1029/2008WR007645.

Walsh, J., and Coauthors, 2014: Our changing climate. Climate Change Impacts in the United States: The Third National Climate Assessment, J. M. Melillo, T. Richmond, and G. W. Yohe, Eds., U.S. Global Change Research Program, 19-67.

Wang, H., S. Schubert, M. Suarez, J. Chen, M. Hoerling, A. Kumar, and P. Pegion, 2009: Attribution of the seasonality and regionality in climate trends over the United States during 19502000. J. Climate, 22, 2571-2590, doi:10.1175/2008JCLI2359.1.

Wessel, P., and W. H. F. Smith, 1995: New version of the generic mapping tools. Eos, Trans. Amer. Geophys. Union, 76, 329329, doi:10.1029/95EO00198.

Zhang, Y. K., and K. E. Schilling, 2006: Increasing streamflow and baseflow in Mississippi River since the 1940s: Effect of land use change. J. Hydrol., 324, 412-422, doi:10.1016/j.jhydrol.2005.09.033. 
Copyright of Journal of Climate is the property of American Meteorological Society and its content may not be copied or emailed to multiple sites or posted to a listserv without the copyright holder's express written permission. However, users may print, download, or email articles for individual use. 